\title{
WCZESNONEOLITYCZNE NARZĘDZIA KAMIENNE $Z$ POBRZEŻA KOSZALIŃSKIEGO
}

\author{
EARLY NEOLITHIC STONE TOOLS FROM THE KOSZALIN SEA-COST
}

\author{
Jolanta Ilkiewicz \\ Muzeum w Koszalinie \\ ul. Młyńska 37/39, 75-420 Koszalin, Poland
}

\begin{abstract}
The article is aimed at analysis and classification of 47 stone tools discovered in the Koszalin Coast (the Baltic Coast), which are taxonomically attributed to the 'Band' forms and the early Neolithic-type so-called 'Northern' - axes ('Walzenbeile').
\end{abstract}

Pobrzeże Koszalińskie ${ }^{1}$ jest częścią Pobrzeży Południowobałtyckich, położoną pomiędzy doliną dolnej Parsęty a okolicami przylądka Rozewie. Obejmuje wąski pas wybrzeża o szerokości 25-30 km i tylko wzdłuż Parsęty sięga on do $60 \mathrm{~km}$ od brzegu morskiego. Powierzchnia makroregionu wynosi ok. 6,5 tys. $\mathrm{km}^{2}$. Różni się ono wyraźnie od głęboko wysuniętego na południe Pobrzeża Szczecińskiego z jednej strony oraz otaczającego Zatokę Gdańską Pobrzeża Gdańskiego. Od Pojezierza Zachodniopomorskiego oddzielone jest stopniem terenowym wysokości 50-100 m. Wydziela się tu, obok charakterystycznego pasa nadmorskiego (Wybrzeże Słowińskie), szereg bezjeziornych wysoczyzn morenowych, przeciętych dolinami rzek Parsęty, Radwi, Grabowej, Wieprzy, Słupi, Łupawy, Łeby oraz częściowo martwymi odcinkami pradolin. Na przełomie mezolitu i neolitu (późny okres atlantycki/ wczesny okres subborealny) jego rozwój kulturowy, jak pokazują najnowsze, niestety niezbyt liczne badania, przebiegał podobnie jak pozostałych części Pobrzeży Południowobałtyckich od lokalnych grup późnoertebøllskich (uważanych obecnie raczej za protoneolityczne, niż mezolityczne), przez inicjalne stadia KPL ${ }^{2}$ do klasycznych faz tej ostatniej kultury. Nie wyklucza się obecności innych społeczności postmezolitycznych ${ }^{3}$. Przez cały wczesny

\footnotetext{
${ }^{1}$ Kondracki 1980 , s. $269-272$.

${ }^{2} \mathrm{~W}$ pracy zastosowano powszechnie używane skróty kultur neolitycznych: $\mathrm{KCW}$ - kultura ceramiki wstęgowej, KCWR - kultura ceramiki wstęgowej rytej, KCWK - kultura ceramiki wstęgowej kłutej, KPCW - kultura późnej ceramiki wstęgowej, KPL - kultura pucharów lejkowatych.

${ }^{3} \mathrm{~J}$ ankowska 1990; G a liński 1990, 1992, 1992a; Il ki ewicz 1997, 1998; Czerniak, Kabaciński 1997, Kobusiewicz 1999; Wierzbicki 1999.
} 
neolit ${ }^{4}$ przeważal niewątpliwie zachodni i północno-zachodni kierunek wpływów kulturowych, zmienil się on dopiero w młodszym neolicie, kiedy zaczęły przeważać wpływy południowe (z północnej Wielkopolski?) z klasycznych faz grupy wschodniej $\mathrm{KPL}^{5}$. Świadczy o tym również kierunek rozprzestrzeniania się idei megalitycznej. Z nielicznymi wyjątkami dotarła na Pomorze tylko najstarsza forma grobu megalitycznego - grobowiec bezkomorowy. Młodsze formy grobów - wielopochówkowe megalityczne grobowce komorowe, charakterystyczne dla młodszych faz grupy północnej KPL - w zasadzie nie występują na wschód od Odry (jeden taki grobowiec zachował się na cmentarzysku megalitycznym w Borkowie, gm. Malechowo, w dorzeczu Grabowej). Ostatnie odkrycia grobowców megalitycznych (bezkomorowych) w środkowej części polskiego wybrzeża - w dolinie Radwi ${ }^{6}$ (Mostowo i Rosnowo, gm. Manowo, pow. Koszalin) zdają się świadczyć, że intensywność osadnictwa pucharowego była tu znacznie większa, niż dotychczas zakładano. Niewielka liczba znanych stanowisk wynika niewątpliwie ze stanu badań, świadczy o tym też fakt odkrywania materiałów KPL przy okazji badań stanowisk z innych okresów chronologicznych (np. tzw. skupisko nadparsęckie w okolicach Białogardu $)^{7}$.

Rozpoznanie wczesno- i środkowoholoceńskiego osadnictwa Pobrzeży Południowobałtyckich jest tym trudniejsze, że leżą one w strefie polodowcowej depresji izostatycznej, co spowodowało, że wraz z eustatycznym podniesieniem się poziomu morza część dawnego wybrzeża znalazła się pod wodą i jest niedostępna rozpoznaniu archeologicznemu, zubażając i tak niewielką bazę źródlową dla rozpoznania transformacji kulturowej tych terenów na przełomie neolitu i mezolitu. Trudno ocenić rozmiary i szczegółowa chronologię tego osadnictwa, ponieważ jedynymi jego dowodami są przypadkowo odkrywane artefakty wymywane spod dna i wyrzucane na brzeg morza. Stanowia one liczną grupę wszystkich znalezisk luźnych z Pobrzeża Koszalińskiego. Większość z nich to narzędzia kamienne i rogowe, głównie formy interkulturowe, o niezbyt precyzyjnie ustalonej chronologii. Wydzielić można wśród nich dużą grupę narzędzi kamiennych o silnie zaznaczonej odrębności morfologicznej, wiązanych taksonomicznie ze „wstęgowym" kregiem kulturowym. Metrykę wczesnoneolityczną przypisuje się też charakterystycznym formom uważanym za „wczesne" narzędzia „północne” - siekierom o przekroju okragtym i owalnym (tzw. Walzenbeile).

Artykuł jest próbą zebrania i podsumowania dostępnych danych o tych narzędziach z Pobrzeża Koszalińskiego, które charakteryzuje się sporą ich koncentracją ( 23 „radlice”, 16 toporów, 2 ,motyki” oraz 6 siekier).

Większość z 47 narzędzi objętych opracowaniem stanowią znaleziska luźne, głównie jeszcze $\mathrm{z}$ odkryć przedwojennych, wiele $\mathrm{z}$ nich nie zachowało się do naszych czasów, znane są tylko ze wzmianek archiwalnych i literatury, część z nich znajduje się obecnie w zbiorach Muzeum w Koszalinie (zdekompletowane zbiory dawnych niemieckich

\footnotetext{
${ }^{4}$ W periodyzacji kultur „północnych”, por. uwagi na temat periodyzacji lokalnych - C z e r n i a k 1994, s. 35.

${ }^{5} \mathrm{~J}$ an k ow s k 1990 , s. $246 \mathrm{n}$.

${ }^{6}$ I 1 kiewicz 2001.

Krzyszowski 1981.
} 


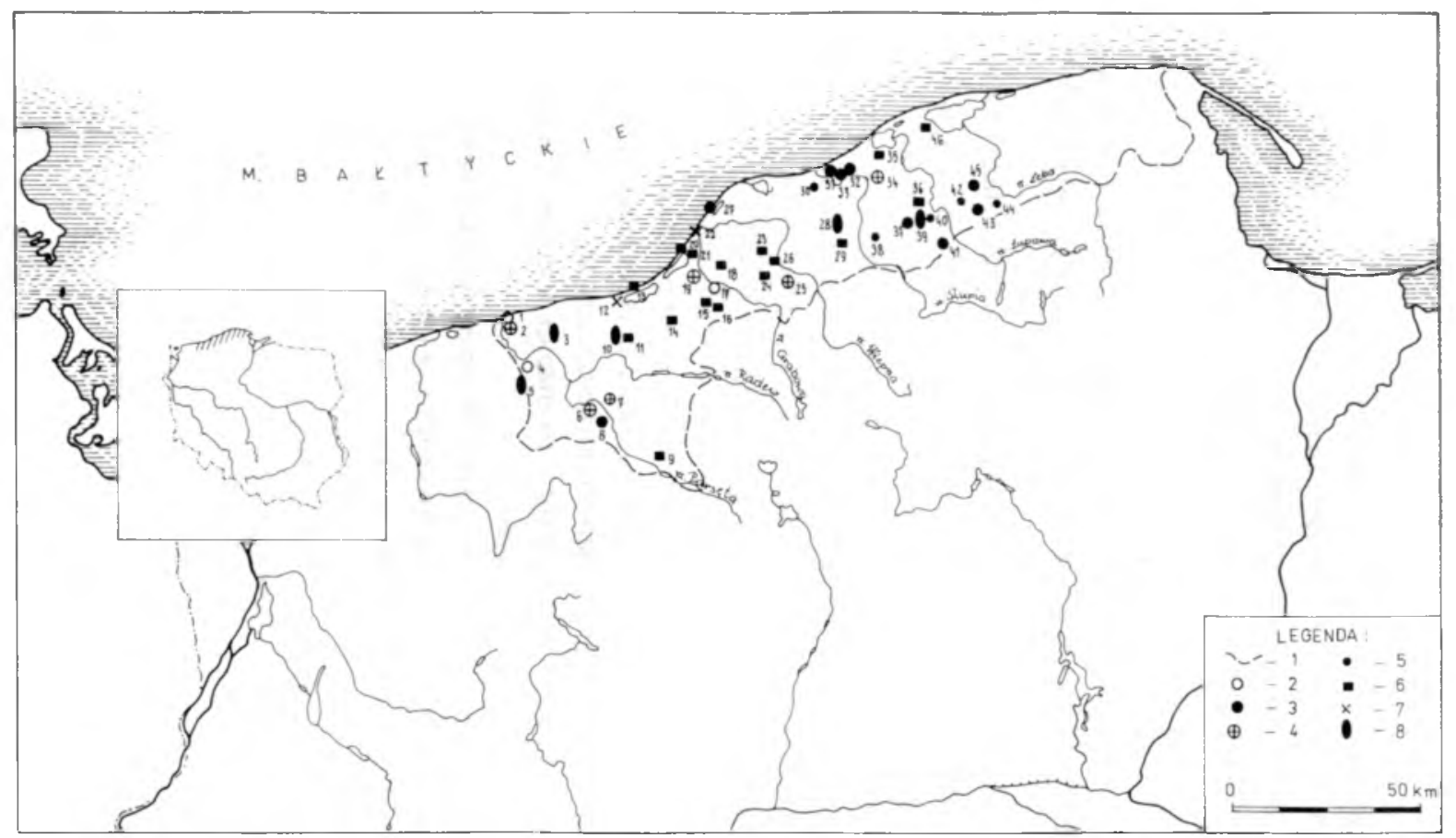

Ryc. 1. Kartografia stanowisk. Legenda: 1 - granice Pobrzeża Koszalińskiego, 2 - radlice klasycznie wstęgowe „wczesne”, 3 - radlice klasycznie wstęgowe „póżne”, 4 - „Plättbolzen”, 5 - fragmenty oraz radlice nieokreślone typologicznie, 6 - topory, 7 - motyki, 8 - siekiery.

Wykaz miejscowości do mapy: 1,2 - Kołobrzeg, 3 - Jazy, 4 - Gościno, 5 - Kamica, 6 - Gruszewo, 7,8 - Białogard. 9 - Wielanowo, 10 - Gorawino, 11 - Cieszyn, 12 - Mielenko, 13 - Unieście, 14 - Sierakowo, 15 - Niemica, 16 - Drzeńsko, 17 - Święcianowo, 18,19 - Boryszewo, 20,21 - Dąbki, 22 - Bobolin, 23 - Bobrowice, 24 - Smardzewo, 25,26 - Slawno, 27 - Kopań, 28 - Kończewo, 29 - Bierkowo, 30 - Pęplino, 31 - Machowinko. 32,33 - Słupska, 39,40 - Łojewo, 41 - Sycewice, 42 - Runowo, 43 - Wieliszewo, 44 - Jawory

Abb. 1. Kartierung der Fundplätze. Legende: 1 - Grenze der Region „Pobrzeże Koszalińskie”, 2 - Dechsel der „frühen” Bandkeramik, 3 - Dechsel der „späten” Bandkeramik, 4 - „Plättbolzen”, 5 - Fragmente sowie typologisch nicht bestimmbare Dechsel, 6 - Äxte, 7 - Hacken, 8 - Beile 
muzeów w Darłowie i Słupsku). W zbiorach Muzeum w Koszalinie znajduje się też 6 narzędzi odkrytych w ostatnich latach, tylko dwa z nich mają określony kontekst kulturowy (Dąbki, stanowisko 9 - późny okres atlantycki, stanowisko związane z ertebøllskim kręgiem kulturowym ${ }^{8}$ ), pozostałe są znaleziskami luźnymi, tylko jedno z nich zostało dotychczas opublikowane".

W zakresie taksonomii typologiczno-chronologicznej narzędzi kamiennych oparto się na ustaleniach L. Czerniaka ${ }^{10}$, zachowując jego oznaczenia grup typologicznych i ich umowne nazwy słowne. Skrócony opis wszystkich narzędzi załączony jest na końcu opracowania w formie katalogu. Na mapie (ryc. 1) zaznaczono ich lokalizację.

\section{„Radlice”}

(formy o płasko-wypukłym przekroju poprzecznym w kształcie „kopyta szewskiego”, bez otworów, z otworem równoległym do ostrza lub prostopadłym do ostrza)

Do grupy typologicznej umownie nazwanej ,radlicami” L. Czerniak zaliczył nie tylko „klasyczne” formy z otworem równoległym do ostrza, ale rozszerzył też nazwę na formy z otworem prostopadłym (tzw. Plättbolzen) oraz tzw. wysokie i średniowysokie „kopyta szewskie" bez otworów, szczegółowego podziału dokonując na podstawie kryterium lokalizacji otworu oraz wysokości przekroju. „Rozszerzoną” definicję ,radlic” zastosowano również do opracowywanych materiałów. Nazwa ta jest czysto umowna i nie ma oczywiście żadnego związku z rzeczywistą funkcją narzędzi, uważanych obecnie generalnie za narzędzia wielofunkcyjne, związane głównie z obróbką drewna.

Za narzędzia klasycznie wstęgowe, ,wczesne" uznawane są formy niskie i średniowysokie bez otworów (typ IB3,1111/1121), synchronizowane z horyzontem chronologicznym KCWR ${ }^{\prime \prime}$. Z terenów objętych opracowaniem pochodzą trzy tego typu narzędzia (ryc. 2): Gościno (nr 4 na mapie) i Kołobrzeg (nr 1 na mapie) w dolinie Parsęty oraz Święcianowo (nr 17 na mapie) w dolinie Grabowej.

Za formy klasycznie wstęgowe ,późne” uznawane są formy wysokie bez otworów (IB3,1131) - jedyny egzemplarz znany jest ze Świecichowa (nr 37 na mapie) z Wysoczyzny Damnickiej (ryc. 3) - oraz formy niskie i średniowysokie z otworem równoległym do ostrza (IB3,1 112/1122), których na omawianym obszarze odkryto osiem (w nawiasach po miejscowości nr na mapie - ryc. 1): Kopań (27, ryc. 4:3), Machowinko (31), Machowino (2 okazy - 32 i 33), Stowięcino (45), Sycewice (41, ryc. 4:2), Wieliszewo (43) i okolice Białogardu (8, ryc. 4:1). Paralelizuje się je najwcześniej z III fazą $\mathrm{KCWK}^{12}$.

\footnotetext{
${ }^{8}$ Il kiewicz 1989.

${ }^{9}$ Ilkiewicz 2001 a.

${ }^{10} \mathrm{Czerniak} 1980$, s. $80-88$.

${ }^{11}$ Vencl 1960, s. 24, 25; Siuchniński 1972, s. 45 n; Grygiel 1976, s. 107; Czerniak 1980 , s. 82 .

${ }^{12}$ Vencl 1960 , s. 26, 27; Brandt 1967, s. 15-16; S i u chniński 1972, s. 46 n.; Czerniak 1980, s. 82 .
} 

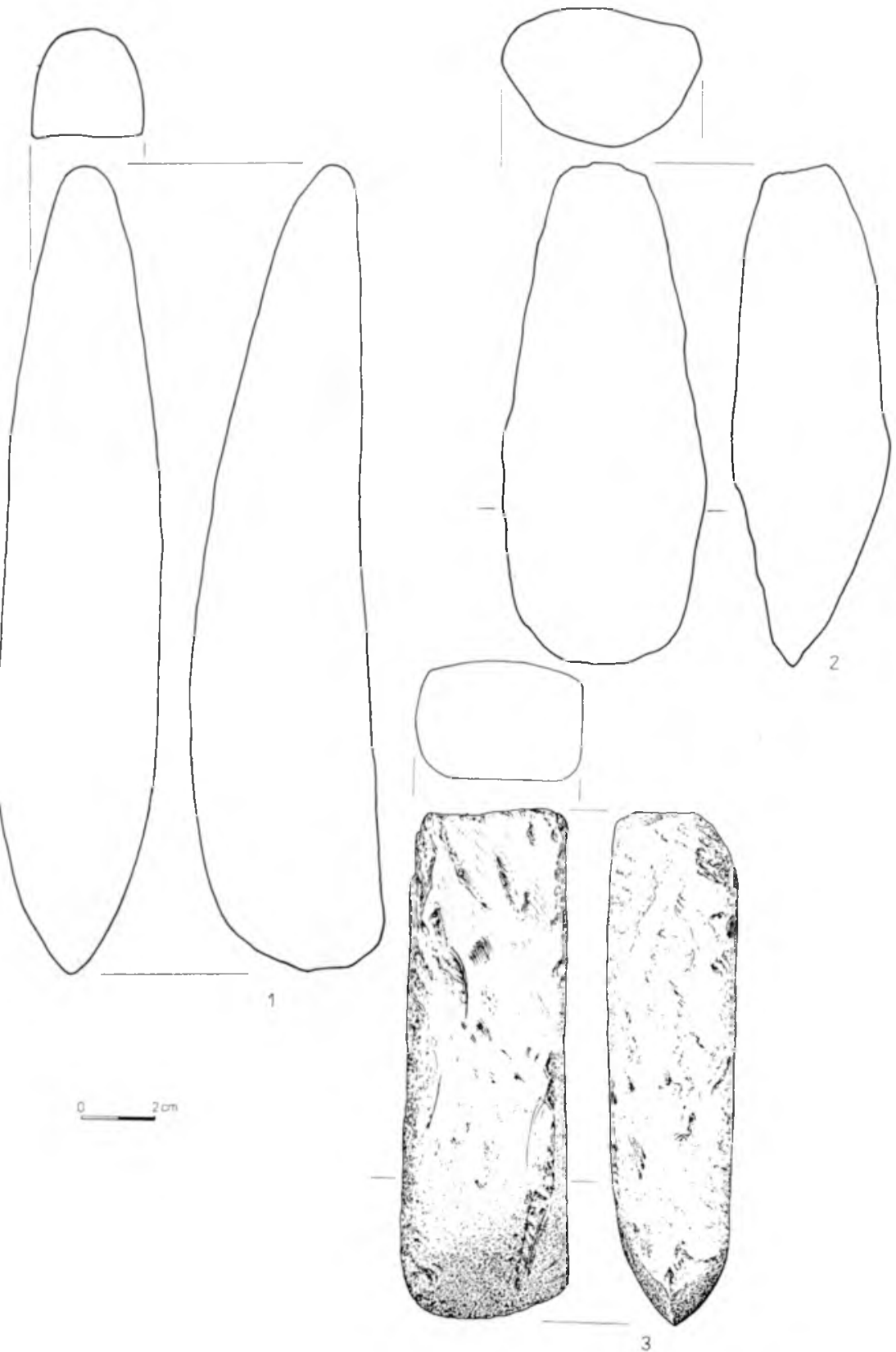

Ryc. 2. Radlice klasycznie wstęgowe „wczesne”: 1 - Kołobrzeg, 2 - Gościno, gm. Gościno, 3 - Święcianowo, gm. Malechowo. Rys. B. Kramer (1,2 wg arch.)

Abb. 2. Dechsel der „frühen” Bandkeramik: 1 - Kołobrzeg, 2 - Gościno, Gem. Gościno, 3 - Święcianowo, Gem. Malechowo. Zeichn. B. Kammer (1,2 nach Archiv) 


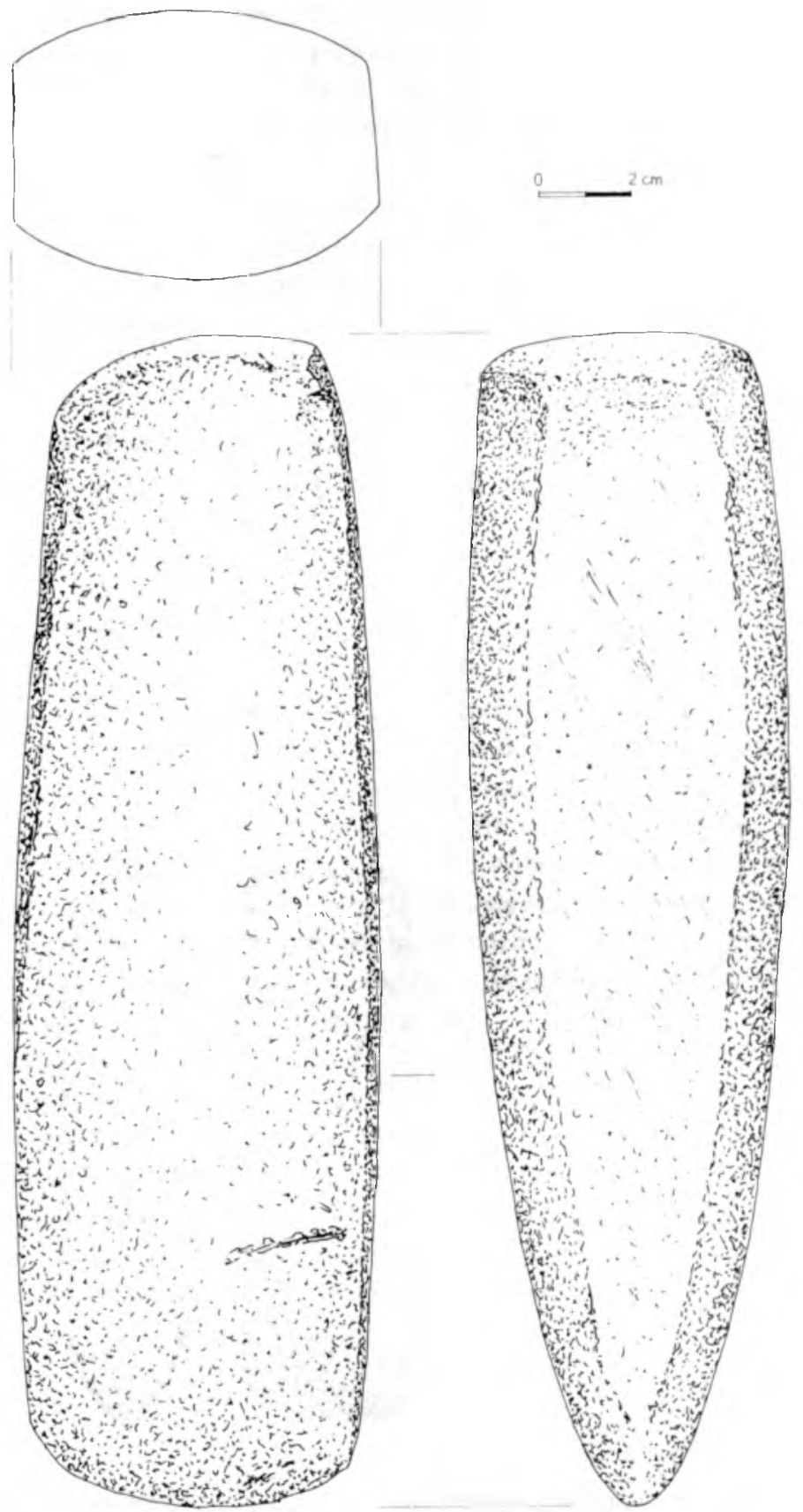

Ryc. 3. Wysoka radlica bez otworu - Świecichowo, gm. Damnica. Rys. B. Kammer Abb. 3. Hoher Dechsel ohne Durchlochung, Świecichowo, Gem. Damnica. Zeichn. B. Kammer 

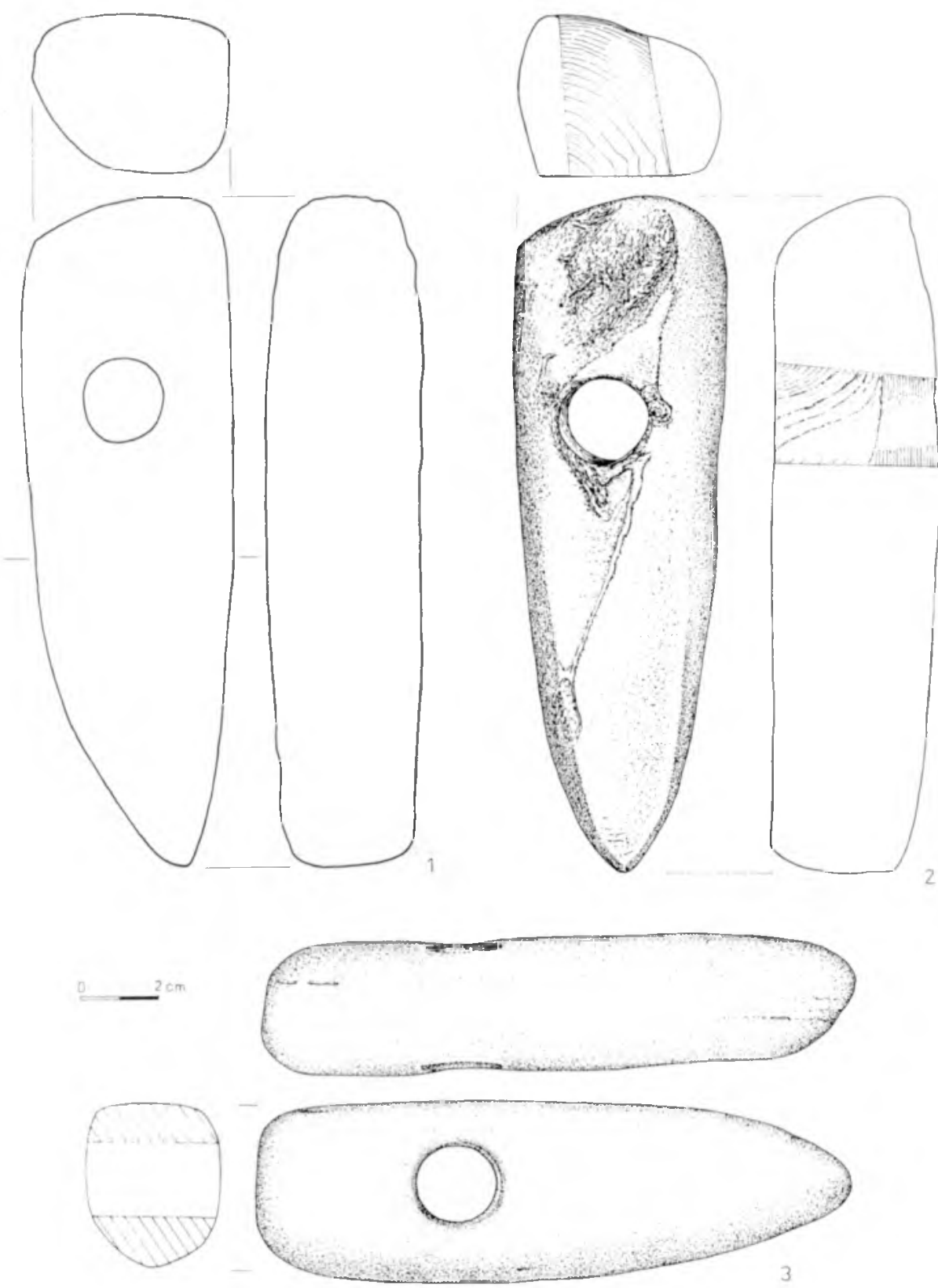

Ryc. 4. Radlice klasycznie wstęgowe „późne”: 1 - okolice Białogardu (wg arch.), 2 - Sycewice, gm. Kobylnica, 3 - Kopań, gm. Darłowo. Rys. B. Kammer 1-2, G. Bezowska - 3

Abb. 4. Dechsel der "späten” Bandkeramik: 1 - Umgebung von Białogard (nach Archiv), 2 - Sycewice, Gem. Kobylnica, 3 - Kopań, Gem. Darłowo. 1-2 Zeichn. B. Kammer, 3 Zeichn. G. Bezowska 


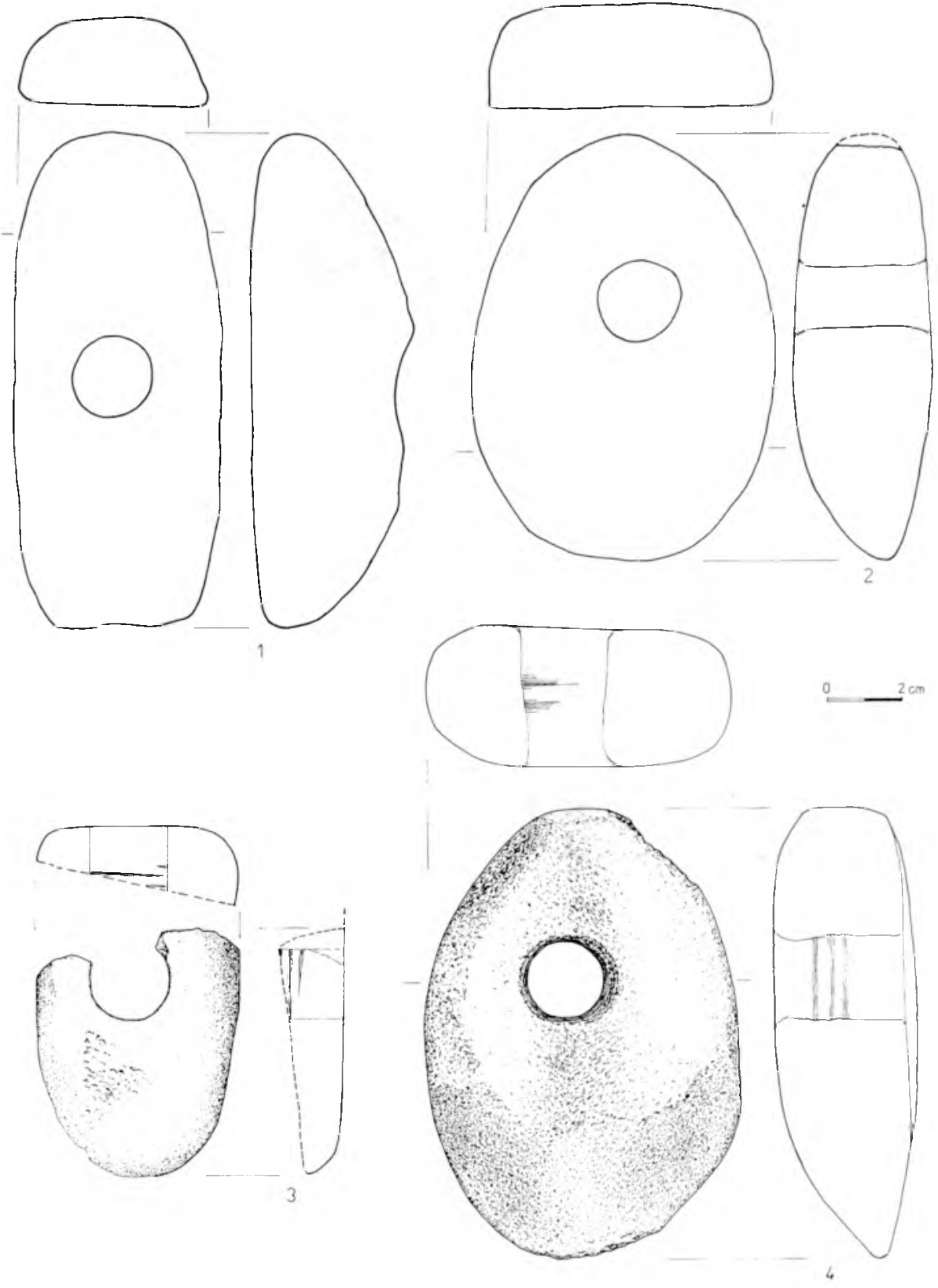

Ryc. 5. Radlice tzw. Plättbolzen (niskie i średniowysokie): 1 - Białogard, 2 - Gruszewo, gm. Białogard, 3 - Osieki Słupskie, gm. Ustka, 4 - okolice Sławna. Rys. B. Kammer (1,2 - wg arch.)

Abb. 5. Dechsel, sog. Plättbolzen (niedrige und mittelhohe): 1 - Białogard, 2 - Gruszewo, Gem. Białogard, 3 - Osieki Słupskie, Gem. Ustka, 4 - Umgebung von Sławno. Zeichn. B. Kammer (1, 2 nach Archiv) 


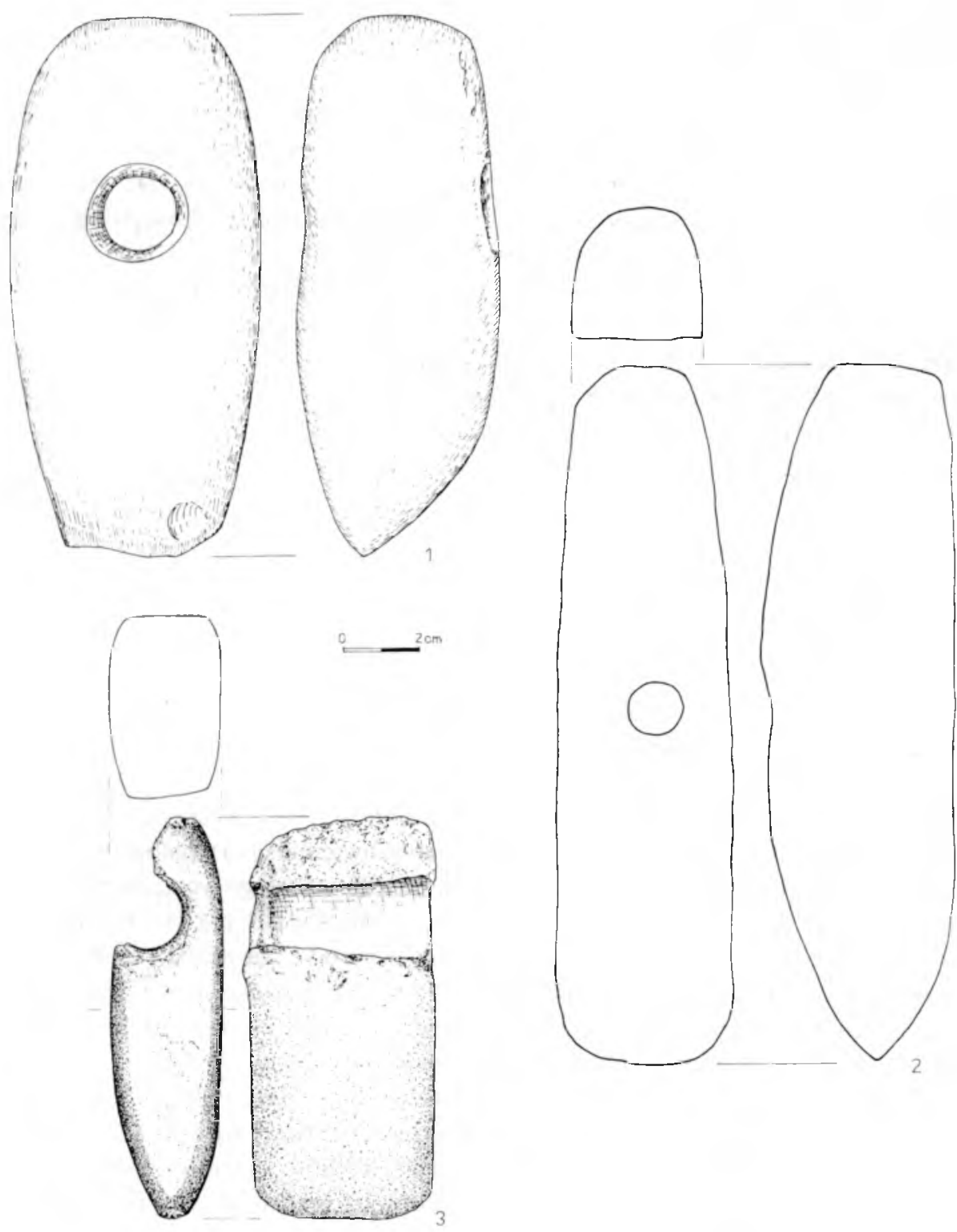

Ryc. 6. Wysokie radlice tzw. Plättbolzen: 1 - Boryszewo, gm. Darłowo, 2 - Kołobrzeg, 3 - fragment radlicy: Łojewo, gm. Damnica. Rys. B. Kammer (1,2 wg arch.)

Abb. 6. Hohe Dechsel, sog. Plättbolzen: 1 - Boryszewo, Gem. Darłowo, 2 - Kołobrzeg, 3 - Dechselfragment von Łojewo, Gem. Damnica. Zeichn. B. Kammer (1, 2 nach Archiv) 
Za późniejsze od nich uznaje się formy $\mathrm{z}$ otworem prostopadłym do ostrza (IB3,1113/1123/1133), tzw. Plättbolzen, synchronizowane z późnymi fazami KCWK, kulturą Rössen, fazą IIb kujawskiej KPCW. Formy wysokie (1133) uznawane są za jeszcze późniejsze ${ }^{13}$. Górną granicę ich występowania zdają się wyznaczać egzemplarze wchodzące w skład domniemanych zespołów KPL ${ }^{14}$. Formę tę w zasadzie uważa się za interkulturową. Z Pobrzeża Koszalińskiego znane są cztery okazy form niskich i średniowysokich (IB3,1113/1123) z Białogardu (7, ryc. 5:1), Gruszewa (6, ryc. 5:2) Osiek Słupskich (34, ryc. 5:3) i okolicy Sławna (25, ryc. 5:4) oraz dwie radlice wysokie (1133) z Boryszewa (19, ryc. 6:1) i Kolobrzegu (2, ryc. 6:2).

W zbiorach Muzeum w Koszalinie znajduje się ponadto fragment radlicy nieokreślony typologicznie (Łojewo, nr 40 na mapie, ryc. 6:3). Za nieokreślone typologicznie uznano też 4 narzędzia, znane ze wzmianek w literaturze ${ }^{15}$, wszystkie pochodzą $z$ dawnego powiatu słupskiego: Jawory (44), Krępa Słupska (38), Pęplino (30), Runowo (42). Radlica z Krępy miała częściowo nawiercony otwór, okaz z Pęplina zapewne należy zaliczyć do tzw. Plättbolzen, brak danych o wymiarach narzędzi.

\section{Topory}

(formy o przekroju czworokątnym, najczęściej nieregularnym, z otworem równoległym do ostrza (stożkowatym lub walcowatym), płasko uformowanymi bokami i skośnym lub zaokraglonym obuchem)

$Z$ terenu Pobrzeża Koszalińskiego pochodzi 16 toporów noszących morfologiczne cechy kamieniarstwa wstęgowego. $12 \mathrm{z}$ nich należy do typu z obuchem nieregularnym (nieoszlifowanym) - typ IB3,121, $5 \mathrm{z}$ nich ma otwór stożkowaty (IB3,1211): Bierkowo (nr 29 na mapie, ryc. 7:1), Komnino (35), Wielanowo (9, ryc. 10:2), Cieszyn (11, ryc. 7:3), Sławno (26, ryc. 9:4). Formy z otworem stożkowatym uważane są za typologicznie starsze od form z otworem walcowatym (typ IB3,1212). Do tego ostatniego typu zaliczono 3 okazy: Dąbki, stan. 9 (21, ryc. 8:1), Siecie (46, ryc. 9:1) i Unieście (13, ryc. 10:1). W przypadku 4 okazów znanych tylko z rysunków archiwalnych nie udało się określić kształtu otworu: Bobrowice (23), Drzeńsko (16), Sierakowo (14, ryc. 9:2), Świecichowo (36). 4 topory mają obuch zaokraglony i walcowaty otwór (typ IB3,1222): Boryszewo (18, ryc. 7:2), Dąbki (20, ryc. 8:2), Niemica (15, ryc. 7:4), Smardzewo (24, ryc. 9:3).

Topory uznawane są generalnie za formy klasycznie wstęgowe ,późne”, synchronizowane najwcześniej z późnymi fazami KCWK (formy z otworem stożkowatym). Nieco późniejszą chronologię przyjmuje się dla pozostałych typów ${ }^{16}$. Górna granica występowania tych form nie jest jasno określona, na ich dłuższe przeżywanie się mogą wskazywać związki z siekierami o okrągłym lub owalnym przekroju poprzecznym ${ }^{17}$. Topór ze

\footnotetext{
${ }^{13}$ B randt 1967, s. 16 n.; S i uchniński 1972, s. 44 n.; Czerniak 1980, s. 82.

${ }^{14} \mathrm{Siuchninski} 1972$, s. 45.

${ }^{15} \mathrm{Witt} 1969$, poz. $106,311: 5$ i 6.

${ }^{16}$ Brandt 1967 , s. 16 n.; Czerniak 1980, s. 82.

${ }^{17} \mathrm{~S}$ i uchniński 1972 , s. 45 n.
} 

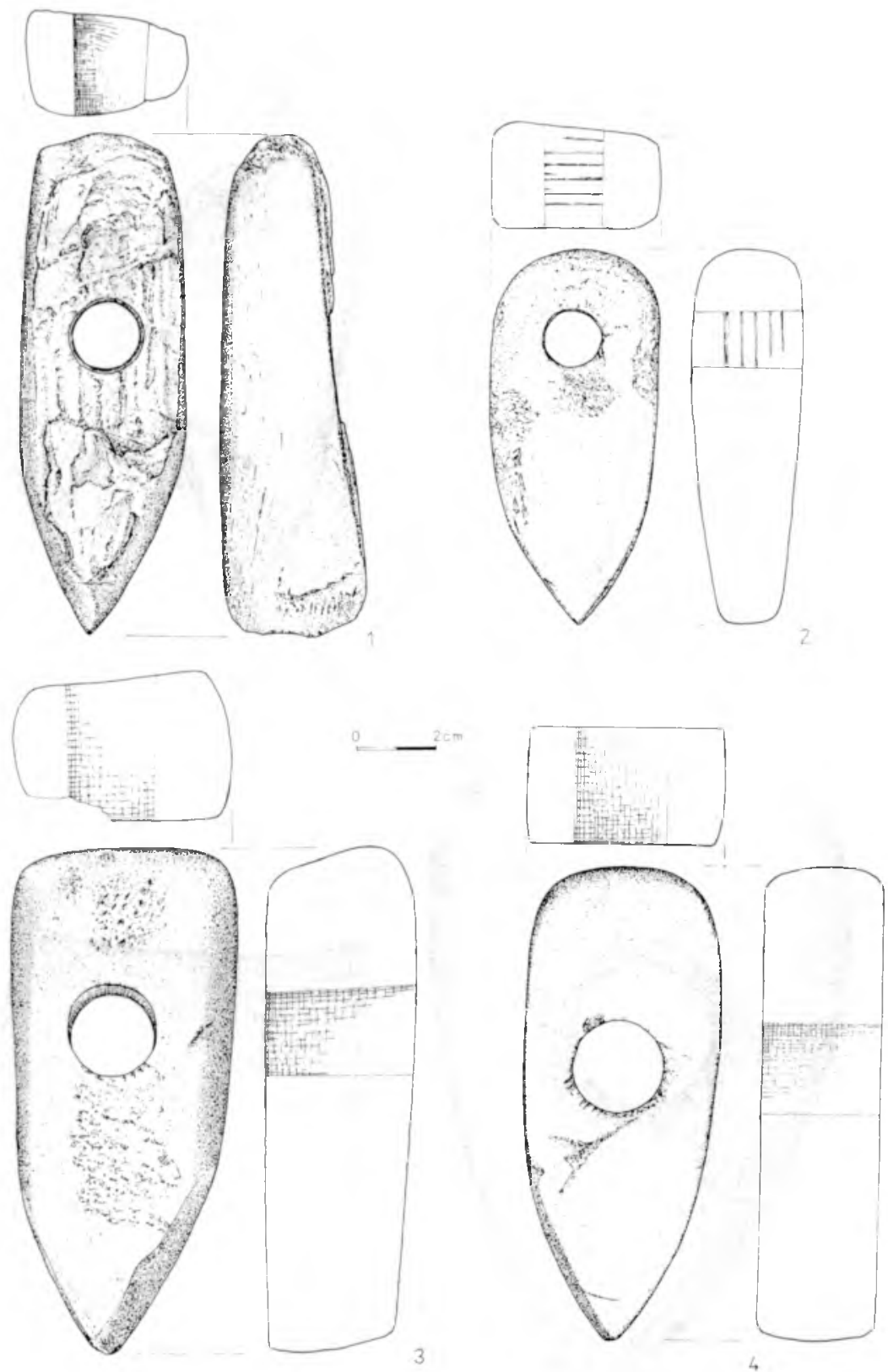

Ryc. 7. Topory: 1 - Bierkowo, gm. Słupsk, 2 - Boryszewo, gm. Darłowo, 3 - Cieszyn, gm. Biesiekierz, 4 - Stawno. Rys. B. Kammer

Abb. 7. Äxte: 1 - Bierkowo, Gem. Słupsk, 2 - Boryszewo, Gem. Darłowo, 3 - Cieszyn, Gem. Biesiekierz, 4 - Stawno. Zeichn. B. Kammer 

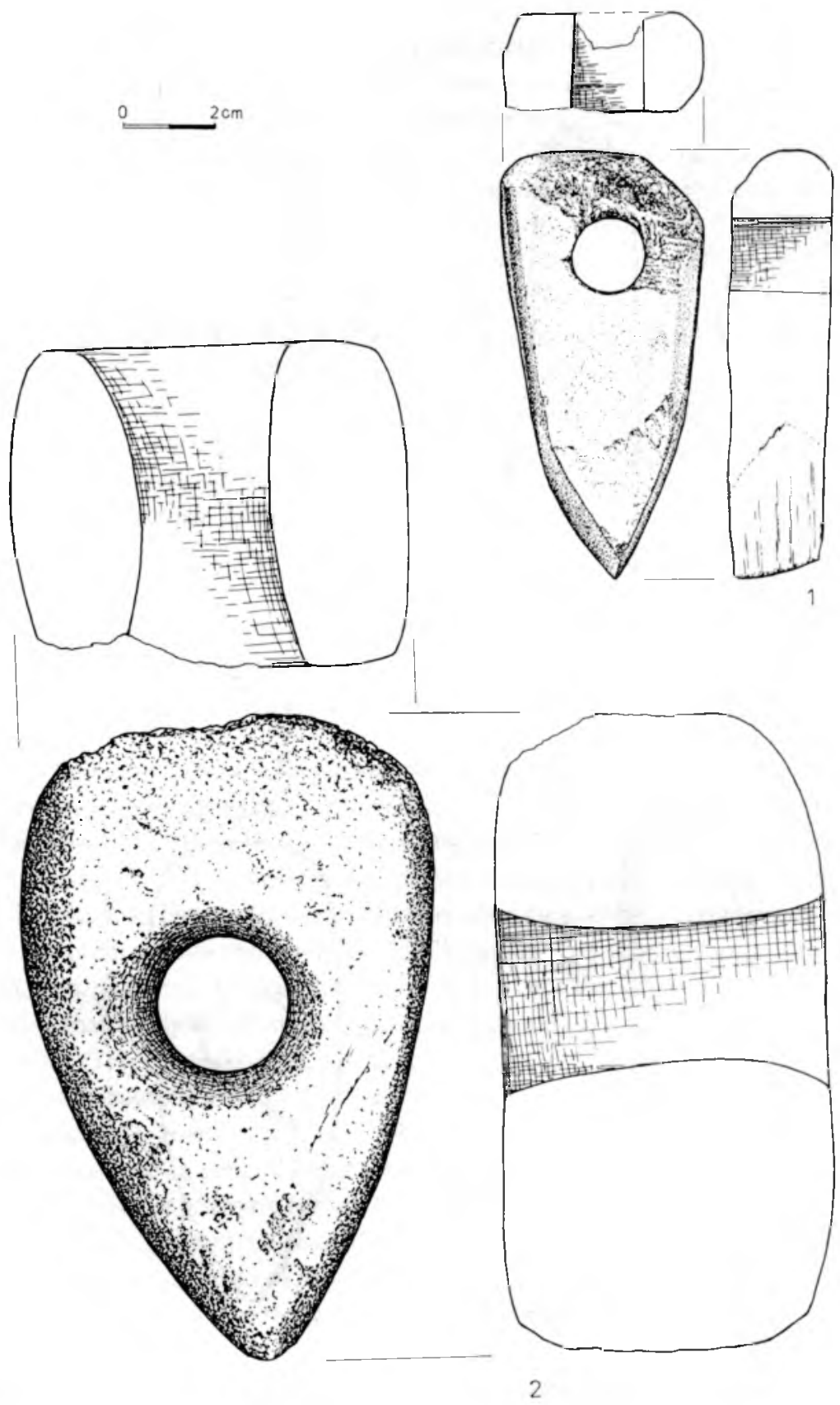

Ryc. 8. Topory: 1 - Dąbki, gm. Darłowo, stan. 9,2 - Dąbki, gm. Darłowo, znaleziska luźne. Rys. B. Kammer Abb. 8. Åxte: 1 - Dąbki, Gem. Darłowo, Fst. 9, 2 - Dąbki, Gem. Darłowo, Einzelfund. Zeichn. B. Kammer 

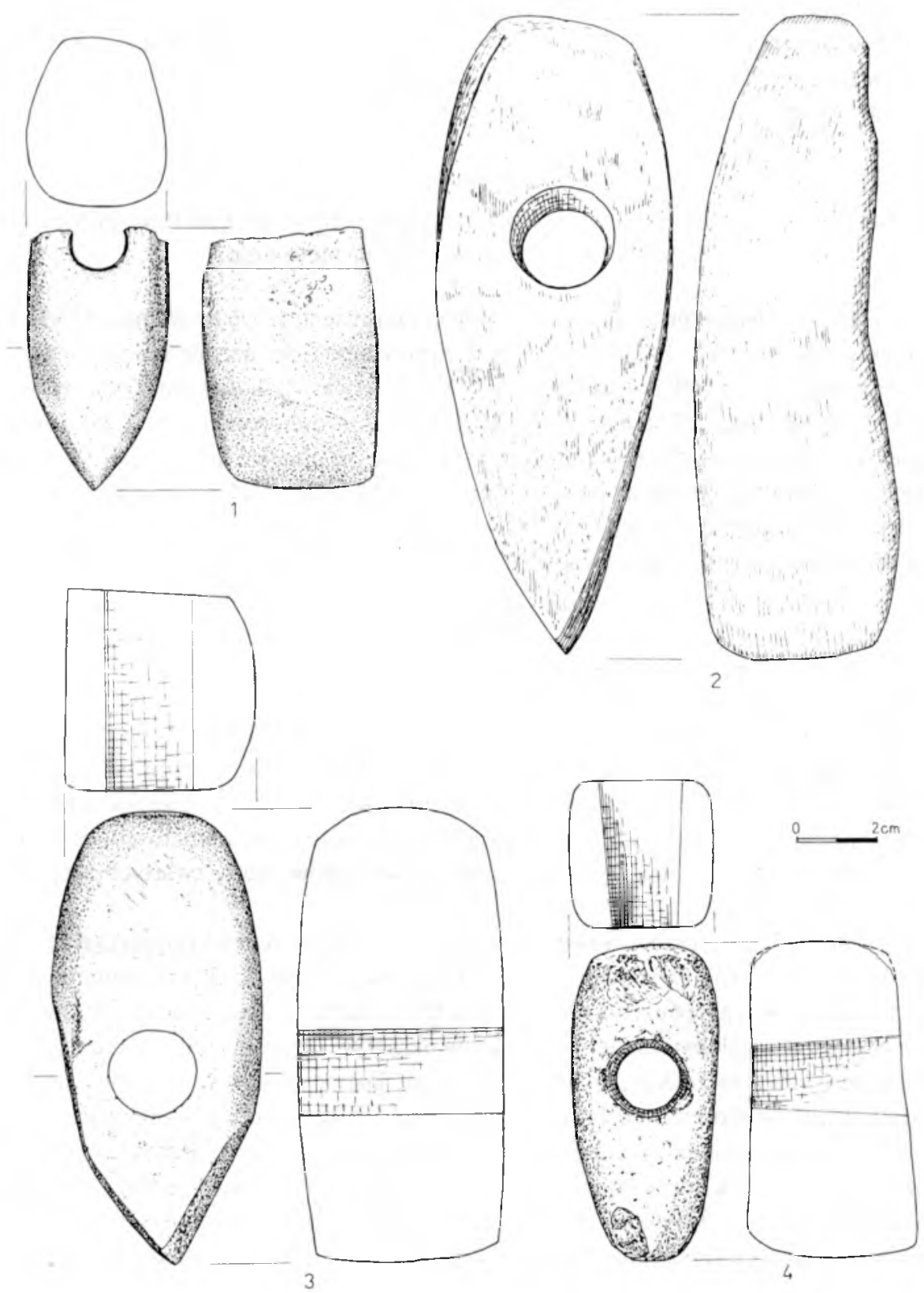

Ryc. 9. Topory: 1 - Siecie, gm. Smołdzino, 2 - Sierakowo, gm. Sianów (wg arch.), 3 - Smardzewo, gm. Sławno, 4 - Sławno. Rys. B. Kammer

Abb. 9. Äxte: 1 - Siecie, Gem. Smołdzino, 2 - Sierakowo, Gem. Sianów (nach Archiv), 3 - Smardzewo, Gem. Sławno, 4 - Sławno. Zeichn. B. Kammer 
stanowiska nr 9 z Dąbek (nr 21 na mapie, ryc. 8:1) pochodzi z warstwy kulturowej w torfowisku datowanej $\mathrm{C}^{14}$ na $5630 \pm 70 \mathrm{BP}(3680 \pm 70 \mathrm{conv}$. bc), związanej z protoneolityczną kulturą typu Ertebølle. Uznany zostal za „import” z kręgu wstęgowego ${ }^{18}$. Jest on jedynym obecnie ,datowanym" narzędziem wstęgowym na Pomorzu.

\section{"Motyki"}

(formy o przekroju płasko-wypukłym, z asymetrycznym ostrzem (tzw. plaskie „kopyta szewskie” lub siekiery asymetryczne)

Motyka z Mielenka (nr 12 na mapie, ryc. 10:3) reprezentuje typ o owalnym przekroju i grubym, zaokrąglonym obuchu (IB3,1332). Formy tego typu łączone sąjeszcze z późnym horyzontem KCWR i zespolami $\mathrm{KCWK}^{19}$. Nietypową, silnie zminiaturyzowaną motykę z Bobolina (nr 12 na mapie, ryc. 10:4) formalnie zaliczono do typu IB3,1364 o przekroju prostokątnym, trójkątnym zarysie i grubym obuchu. Jest ona silnie zużyta i zapewne zniekształcona przez kolejne naprawy (ślady silnego szlifowania na ściankach bocznych, nieregularny obuch). Mimo braku analogii wydaje się nosić cechy kamieniarstwa wstęgowego, choć może bezpieczniej byloby uznać ją za formę interkulturową.

\section{Siekiery}

(formy bez otworów o symetrycznym przekroju i ostrzu)

Za formy wczesnoneolityczne uważa się siekiery o przekroju okrągłym (,Walzenbeile") i przekroju idealnie owalnym lub owalnym z lekko zeszlifowanymi bokami (typy IB3,141-143). Siekiery te na niżu środkowoeuropejskim uznawane są za narzędzia klasycznie ,północne” i ,zachodnie”, genetycznie wiąże się je z kulturami Ertebølle, Cortaillod, Michelsberg ${ }^{20}$. Notuje się sporadyczne ich występowanie w zwartych zespołach wstęgowych ${ }^{21}$.

$Z$ terenu objętego opracowaniem pochodzą trzy siekiery o przekroju okragłym (typ IB3, 141): z Łojewa (nr 39 na mapie, ryc. 11:1), Kamicy (5, ryc. 11:2) i szczególnie efektowna duża siekiera z Kończewa (28, ryc. 12). Dwie pierwsze mają obuch ostry, siekiera z Kończewa zaokraglony. Siekiery o przekroju okragłym uważa się za najstarszy typ siekier kamiennych w zachodniej i północnej Europie. Datuje się je współcześnie z wysokimi „radlicami” $z$ otworem, synchronizując okres ich występowania z przełomem KCWR i KPCW. Siekiery o owalnym przekroju uważane są za „młodszą” odmianę „Walzenbeile". Lączy się je z horyzontem kultur Rössen, Michelsberg, KPL - po fazie MN I neolitu północnego ${ }^{22}$. Siekiera o przekroju owalnym (typ IB3,1421) znana jest z Pobrzeża Koszalińskiego z Gorawina (10, ryc. 13:1), natomiast siekiery o przekroju owalnym

\footnotetext{
${ }^{18}$ I l k i ewicz 1989 , s. 36 , ryc. 10:14.

${ }^{19}$ Grygiel 1976, s. 105 n.; Czerniak 1980, s. 84.

${ }^{20}$ Brandt 1967, s. 127 n.; Czerniak 1980, s. 85.

${ }^{21}$ Brandt 1967, s. 129, 135; Siuchniński 1972, s. 45; Czerniak 1980, s. 85

${ }^{22} \mathrm{Brandt} 1967$, s. 131 n.; Czerniak 1980, s. 85.
} 

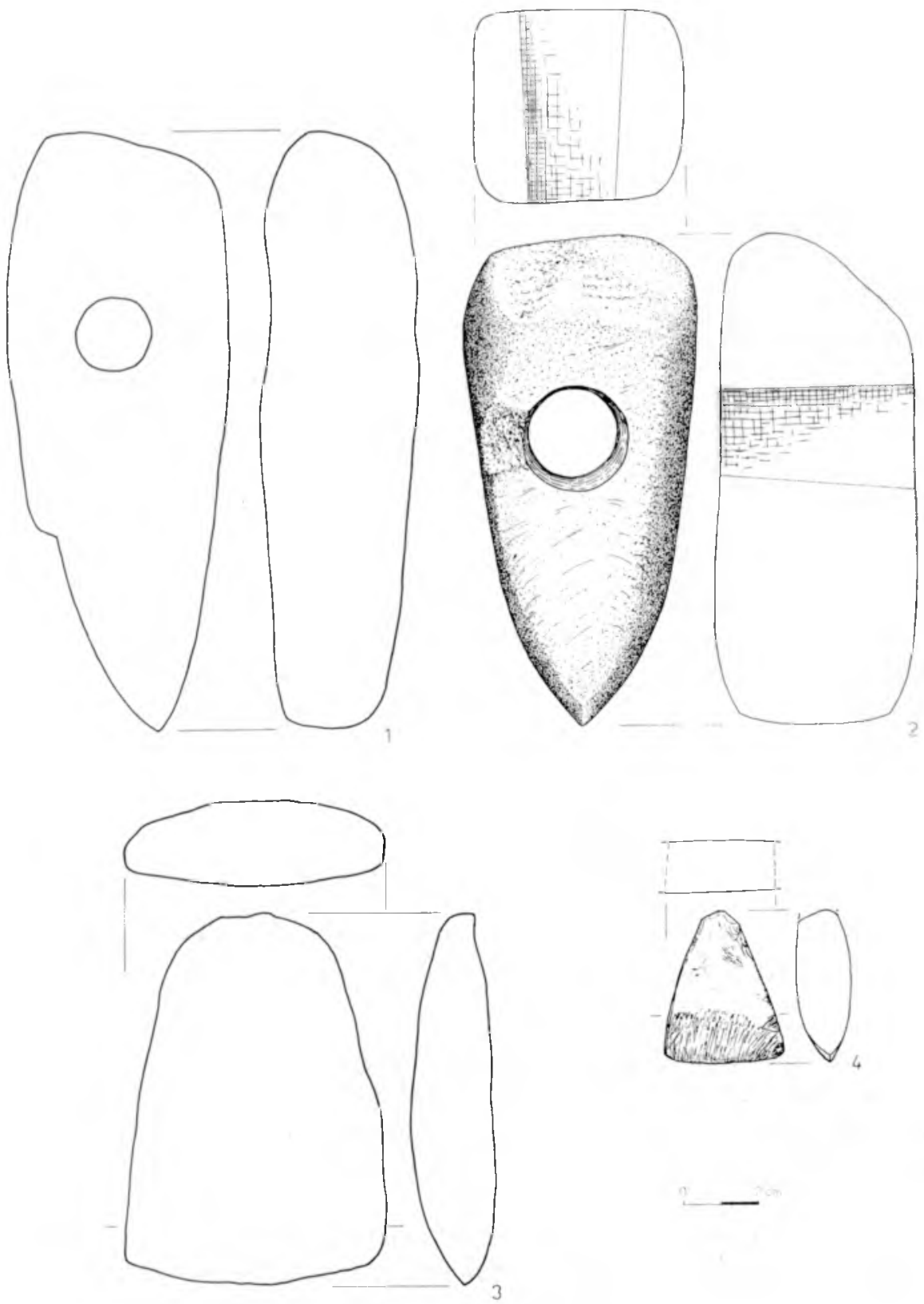

Ryc. 10. Topory: 1 - Unieście, gm. Mielno (wg arch.), 2 - Wielanowo, gm. Grzmiąca. Motyki: 3 - Mielenko, gm. Mielno (wg arch.), 4 - Bobolin, gm. Darłowo. Rys. B. Kammer

Abb. 10. Äxte: 1 - Unieście, Gem. Mielno (nach Archiv), 2 - Wielanowo, Gem. Grzmiąca. Hacken: 3 - Mielenko, Gem. Mielno (nach Archiv), 4 - Bobolin, Gem. Darlowo. Zeichn. B. Kammer 

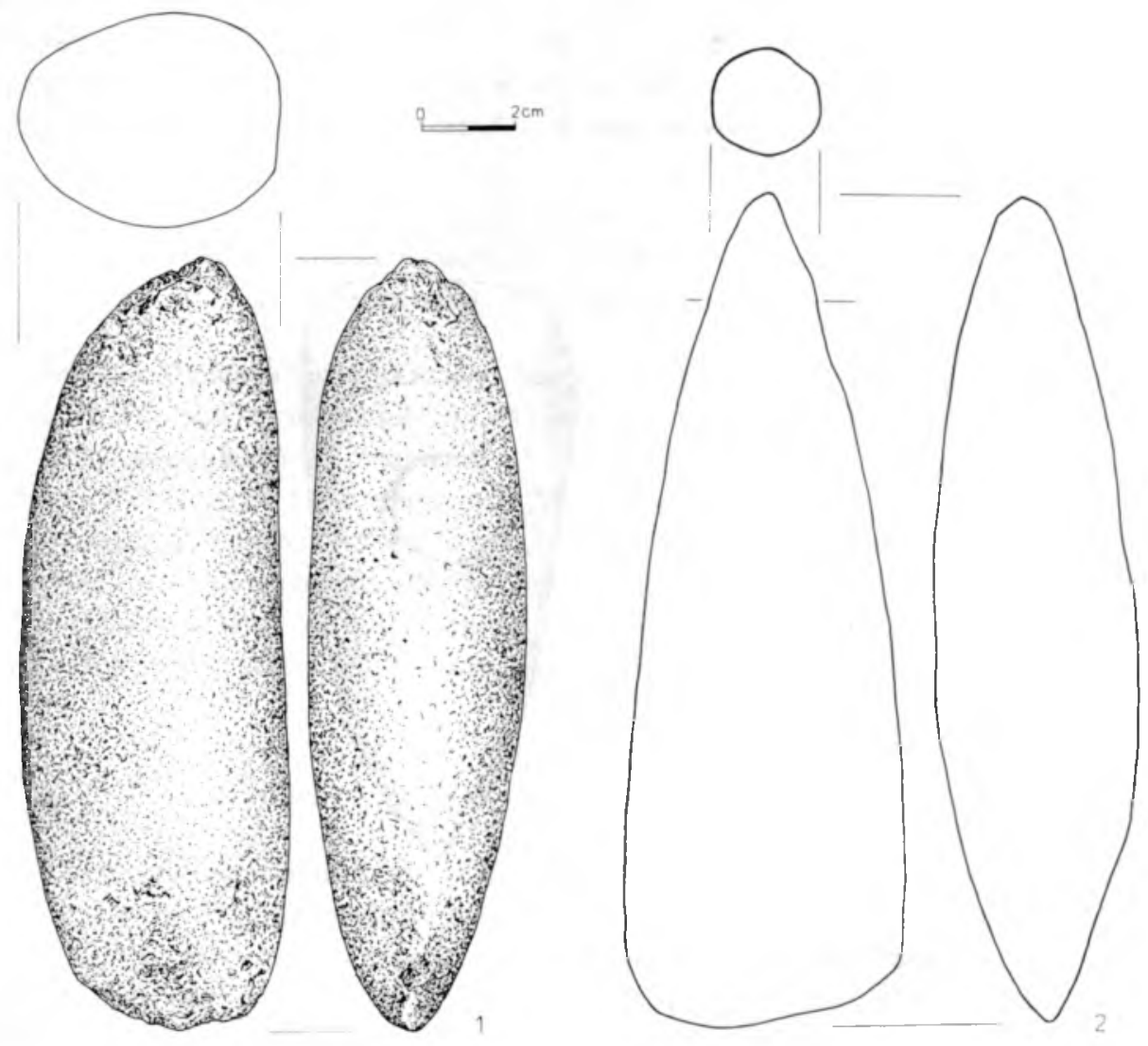

Ryc. 11. Siekiery: 1 - Łojewo. gm. Damnica, 2 - Kamica, gm. Gościno (wg arch.). Rys. B. Kammer Abb. 11. Beile: 1 - Łojewo, Gem. Damnica, 2 - Kamica, Gem. Gościno (nach Archiv). Zeichn. B. Kammer

z lekko zeszlifowanymi bokami (typ IB3,1432) odkryte zostały w Jazach (3; ryc. 13:2) i Dąbkach, stan. $9\left(21\right.$, ryc. 13:3) ${ }^{23}$. Siekiera z Dąbek pochodzi niestety z części „piaskowej” stanowiska, datować można ją więc tylko w szerokich ramach późnego okresu atlantyckiego (najmłodsze daty dla stanowiska 5340/5265 $\pm 60 \mathrm{BP}-$ ok. $3400 / 3300$ conv. bc) ${ }^{24}$.

Znaczne zróżnicowanie morfologiczne wczesnoneolitycznych narzędzi kamiennych z Pobrzeża Koszalińskiego związane jest niewątpliwie z ich zróżnicowaniem chronologicznym. Generalnie wydaje się, że wyróżnić można co najmniej trzy horyzonty chronologiczne

\footnotetext{
${ }^{23} \mathrm{Na}$ mapie ( ryc. 1) i w katalogu obydwa narzędzia kamienne z tego stanowiska oznaczone są jednym symbolem graficznym i tym samym nr (21).

${ }^{24}$ I $1 \mathrm{k}$ i e w ic z 1989.
} 


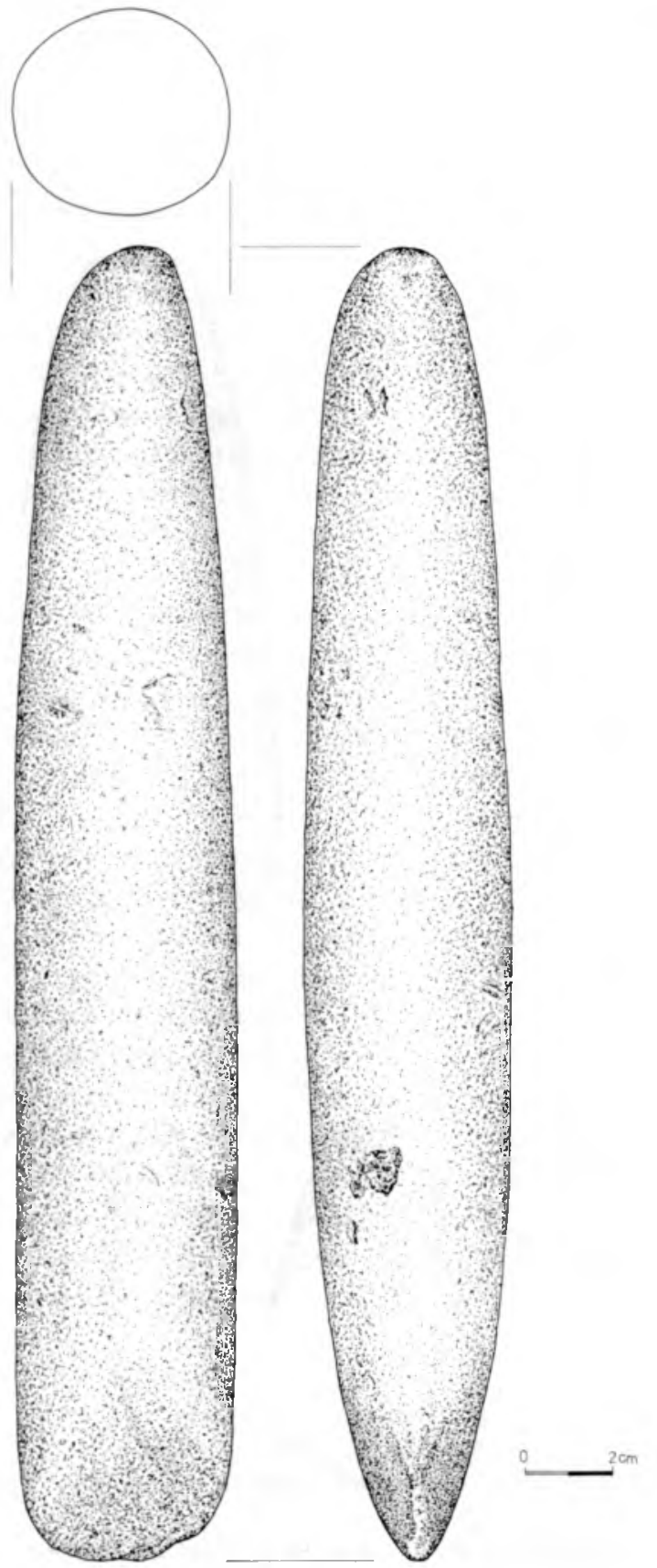

Ryc. 12. Siekiera z Kończewa, gm. Kobylnica. Rys. B. Kammer Abb. 12. Beil aus Kończewo, Gem. Kobylnica. Zeichn. B. Kammer 
108

JOLANTA ILKIEWICZ
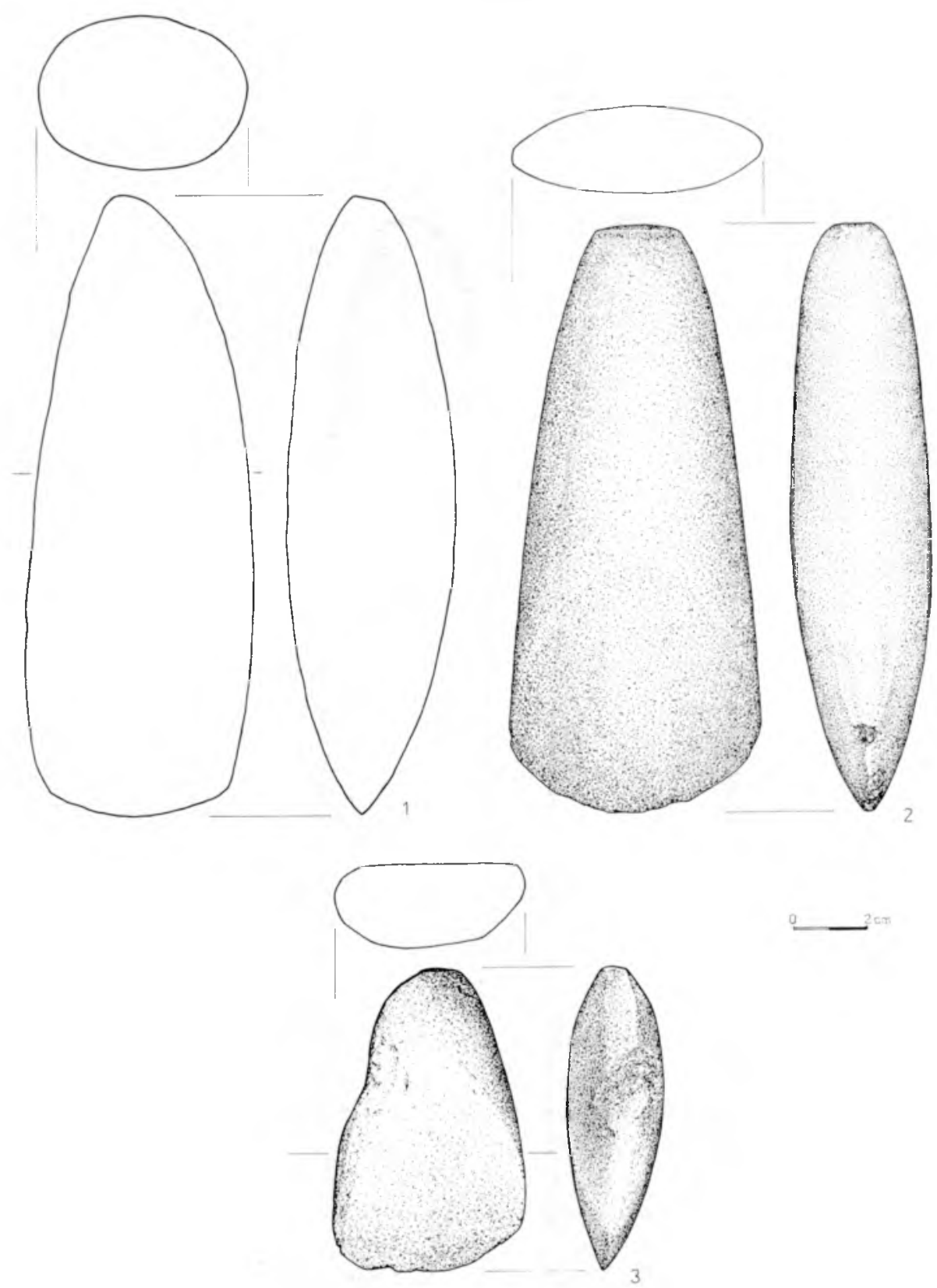

Ryc. 13. Siekiery: 1 - Gorawino, gm. Rymań (wg arch.), 2 - Jazy, gm. Dygowo, 3 - Dąbki, gm. Darlowo, stan. 9. Rys. B. Kammer

Abb. 13. Beile: 1 - Gorawino, Gem. Rymań (nach Archiv), 2 - Jazy, Gem. Dygowo, 3 - Dąbki, Gem. Darłowo, Fst. 9. Zeichn. B. Kammer 
ich napływu. Najstarszy reprezentują ,radlice" niskie i średniowysokie bez otworów klasycznie wstęgowe wczesne - wiązane generalnie z KCWR. Trzy egzemplarze odkryto w zachodniej części regionu - nie przekraczają one od zachodu rzeki Grabowej. Być może z tym samym, albo już z następnym horyzontem łączyć można najstarsze siekiery „północne” („Walzenbeile”) - też tylko trzy okazy (sięgające jednak na zachód aż do Słupi). Drugi horyzont chronologiczny wyznaczają formy określane jako klasycznie wstęgowe „późne” (,radlice” wysokie bez otworów, „radlice” niskie i średniowysokie $\mathrm{z}$ otworem równoległym do ostrza, topory, szczególnie formy z nieregularnym obuchem) oraz generalnie wczesne siekiery ,północne”, w tym młodsze formy o owalnym przekroju. Horyzont ten, z którym wiązać można zdecydowaną większość odkrytych narzędzi, można zapewne paralelizować z młodszymi fazami KCWK i KPCW. Trzeci horyzont wyznaczałaby obecność „Plättbolzen” i zapewne również w dalszym ciągu siekier ,północnych”, niekoniecznie tylko „wczesnych”. Horyzont ten wykraczałby już poza wczesny neolit. Można go określić ogólnie jako ,wczesnopucharowy”. Datowanie okazów odkrytych w Dąbkach, stan. 9, wydaje się potwierdzać, że napływ klasycznie wstęgowych narzędzi kamiennych poza ekumenę wstęgową zgodny był z rytmem przemian kultur tego cyklu na terenach objętych jego zwartym osadnictwem.

Kartografia stanowisk (ryc. 1) wykazuje wyraźny brak interesujących nas narzędzi na wschód od pradoliny Łeby. Nie wydaje się on przypadkowy. Potwierdza zapewne głównie zachodnią (wzdłuż wybrzeża) drogę ich napływu na Pomorze. Pradolina Łeby stanowiła prawdopodobnie ważną barierę kulturową w tym okresie ${ }^{25}$. Pojedyncze egzemplarze narzędzi ,wstęgowych" znajdowane są również w strefie pojezierzy, na południe od Pobrzeża Koszalińskiego ${ }^{26}$. Nie jest wykluczone, że część z nich trafiła tam bezpośrednio ze "wstęgowego" centrum nadodrzańskiego lub od wschodu i południa (z centrum kujawsko-wielkopolskiego), wydaje się jednak, że droga ,nadmorska” też może być brana pod uwage. W kwestii „użytkowników” narzędzi wczesnoneolitycznych, głównie „wstęgowych"w tej części Pomorza należy zgodzić się z J. Wierzbickim" ${ }^{27}$, że mogły to być grupy postmezolityczne, bardziej jednak prawdopodobne wydaje się, że na południowym wybrzeżu Bałtyku ich głównymi użytkownikami były grupy protoneolityczne typu ertebøllskiego ${ }^{2 x}$. Wielorakie powiązania kulturowe obu kręgów kulturowych, szczególnie w horyzoncie chronologicznym KPCW II-III wydają się obecnie niekwestionowane $^{2 y}$. Zaowocowały one późniejszym (w młodszym neolicie) ujednoliceniem kamieniarstwa wstęgowego i ,północnego”.

\footnotetext{
${ }^{29}$ Por. analizę znaczenia rzeki Łupawy dla genezy łupawskiego ugrupowania KPL - W i e r z bi ck i 1999 , s. 245.

${ }^{26} \mathrm{~W}$ iślański 1969, mapa 3; 1970, s. 30, mapa - ryc. I; S i u c hn iński 1972, mapa II.

${ }^{27}$ Wierzbicki 1999 , s. 243.

${ }^{28}$ Narzędzia ,wstęgowe” znane są ze stanowisk ertebøllskiego krçgu kulturowego, nie odkryto ich jednak na żadnym stanowisku mezolitycznym (postmezolitycznym).

${ }^{29}$ Czerniak 1994, s. 120-125; Czerniak, Kabaciński 1997.
} 
WCZESNONEOLITYCZNE NARZĘZIA KAMIENNE Z POBRZEŻA KOSZALIŃSKIEGO

Katalog stanowisk ${ }^{30}$

1. Bialogard (nr 7 na mapie - ryc. 1), gm. Białogard, pow. Białogard, znalezisko luźne, ,radlica” - forma niska z otworem prostopadłym do ostrza (,Plättbolzen”) typ IB3,1113 - ryc. 5:1; wym. 13,2 ×5,5 × 3,7 cm; zb.? (n. Muzeum Białogard); arch. MNS 3; lit. Janocha, Lachowicz 1972, ryc. 10b; Siuchniński 1972 , mapa II, poz. 32; Krzyszowski 1981, s. 5, poz. 8, tabl. 1:4.

2. Bialogard (8) - okolice - miejscowość nieznana, znalezisko luźne, „radlica” forma średniowysoka $z$ otworem równoległym do ostrza - typ IB3,1122 - ryc. 4:1; wym. 17,5 ×5,4 ×3,9 cm; zb.? (n. Muzeum Białogard, nr inw. 4983); lit. K r zy szowski 1981 , s. 250 , poz. 294, tabl. $44: 1$.

3. Bierkowo (29), gm. Słupsk, pow. Słupsk, znalezisko luźne, topór - typ IB3,1212 ryc. $7: 1$; wym. $12,8 \times 4,2 \times 3,5 \mathrm{~cm}$; zb. Muzeum Koszalin, nr kat. 8523 ; lit. W itt 1969 , poz. 45 .

4. Bobolin (22), gm. Darłowo, pow. Sławno, znalezisko luźne, trójkątna w zarysie „motyka" o prostokątnym przekroju i grubym obuchu - typ IB3,1364? - ryc. 10:4; wym. 4,1 × 3,2 × 1,5 cm.; zb. Muzeum Koszalin, nr kat. 10992; lit. K 1 e is t 1955 , s. 24, nr 209; Kle ist 1969, s. 101, nr 209, ryc. 82.

5. Bobrowice (23), gm. Sławno, pow. Slawno, znalezisko luźne, topór - typ IB3,121; wym. ok. $10,0 \times 4,0 \times 4,5 \mathrm{~cm}$; zb.? (n. własność prywatna); lit. K le is t 1969, s. 101 , tabl. 81:1d; Siuchniński 1972, mapa II, poz. 17.

6. Boryszewo (18), gm. Darłowo, pow. Sławno, znalezisko luźne, topór - typ IB3,1222 - ryc. 7:2; wym. 9,5 ×4,3×2,8 cm; zb. Muzeum Koszalin, nr kat. 10997; lit. Kleist 1969, s. 101, nr 239, ryc. 83; S i u chn ińs k i 1972, mapa II, poz. 18.

7. Boryszewo (19), gm. Darłowo, pow. Sławno, znalezisko luźne, ,radlica”, forma wysoka $z$ otworem prostopadlym do ostrza (tzw. Plättbolzen) - typ IB3,1133 - ryc. 6:1; wym. 14,5 × 6,7 ×5,3 cm; zb.? (n. Muzeum Darłowo, nr inw. 1048); lit. K1 e is t 1969, s. 101, nr 237a, ryc. 83; Siuchniński 1972, mapa II, poz. 18.

8. Cieszyn (11), gm. Biesiekierz, pow. Koszalin, znalezisko luźne (1967 r.), topór typ IB3,1212 - ryc. 7:3; wym. 13,4 × 5,0×3,2 cm; zb. Muzeum Koszalin, nr kat. 11341; arch. MK 204/Ko.

9. Dąbki (20), gm. Darłowo, pow. Sławno, znalezisko luźne, topór - typ IB3,1222 ryc. $8: 2$; wym. $14,0 \times 9,0 \times 7,7 \mathrm{~cm}$; zb. Muzeum Koszalin, nr kat. 10092; lit. K le is t 1969 , s. 102 , nr 571 a, ryc. 86 .

10. Dąbki, stan. 9 (21), gm. Darłowo, pow. Sławno, osada/obozowisko, 1 - z warstwy naturalnej w torfowisku (wykop WKT I/81) datowanej C-14 $5630 \pm 70$ BP: topór -

${ }^{30} \mathrm{~W}$ katalogu zastosowano następujące skróty: arch. - archiwum, gm. - gmina, pow. - powiat, lit. literatura, n. - niegdyś, ryc. - rycina, wym. - wymiary (długość $\times$ szerokość $\times$ grubość), zb. - zbiory, MK - Muzeum w Koszalinie, MNS - Muzeum Narodowe w Szczecinie. W nawiasie przy miejscowości podano numer narzędzia na mapie - ryc. 1. 
typ IB3,1212 - ryc. 8:1; zb. Muzeum Koszalin, nr kat. 13120; lit. I 1 ki ew ic z 1989, s. 36, 37, ryc. 10:14; 2 - z ,,krzemienicy” w piaskowej części stanowiska (wykop I/78): siekiera o przekroju owalnym z lekko zeszlifowanymi bokami - typ IB3,1432 - ryc. 13:3; wym. 8,4 ×5,2 × 2,8 cm; zb. Muzeum Koszalin, nr kat. 12637; lit. I1 ki ew icz 1989, s. 36, ryc. 10:13.

11. Drzeńsko (16), gm. Malechowo, pow. Sławno, znalezisko luźne, topór - typ IB3,121; zb.? (n. Muzeum Szczecin, nr inw. 1759); lit. K l e is t 1969, s. 101, nr 321, ryc. 83; Siuchniński 1972, mapa II, poz. 19.

12. Jawory (44), gm. Dębnica Kaszubska, pow. Słupsk, znalezisko luźne, ,radlica” nieokreślona typologicznie; zb.? (n. własność prywata); lit. W it t 1969, poz. 106.

13. Jazy (3), gm. Dygowo, pow. Kołobrzeg, znalezisko luźne ( 1980 r.), siekiera o przekroju owalnym z lekko zeszlifowanymi bokami - typ IB3,1432 - ryc. 13:2; wym. $16,5 \times 6,9 \times 3,9 \mathrm{~cm}$; zb. Muzeum Koszalin, nr kat. 13781; arch. MK 1344/Kł.

14. Gorawino (10), gm. Rymań, pow. Kołobrzeg, znalezisko luźne, siekiera o przekroju owalnym - typ IB3,1421 - ryc. 13:1; wym. 17,2 ×6,0×4,5 cm; zb.? (n. Muzeum Gdańsk); arch. MNS 512; lit. Krzyszowski 1981, s. 84, poz. 78, ryc. 14:1.

15. Gościno (4), gm. Gościno, pow. Kołobrzeg, znalezisko luźne, ,radlica” - forma niska bez otworu - typ IB3,1111 - ryc. 2:2; wym. 13,8 ×5,5×3,7 cm; zb. Muzeum Szczecin; arch. MNS 38/105; lit. Kunke1 1938, s. 321, p. 44; S i u c hn ińs k i 1972, mapa II, poz. 29; Krzyszowski 1981, s. 85, poz. 80, tabl. 14:12.

16. Gruszewo (6), gm. Białogard, pow. Białogard, znalezisko luźne, ,radlica” - forma niska z otworem prostopadłym do ostrza - typ IB3,1113 (tzw. Plättbolzen) - ryc. 5:1; wym. $12,0 \times 8,0 \times 3,6 \mathrm{~cm}$; zb. (n. Muzeum Trzebiatów?); lit. Kunkel 1932, s. 272; J a n o c h a, Lachowicz 1972, s. 30, ryc. 10a; Krzyszowski 1981, s. 88, poz. 87, tabl. 16:2.

17. Kamica (5), gm. Gościno, pow. Kolobrzeg, znalezisko luźne, siekiera o przekroju okrągłym (,Walzenbeile”) - typ IB3,1411 - ryc. 11:2; wym. 17,5 ×6,0×4,5 cm; zb.? (n. Muzeum Kołobrzeg, nr inw. 43); arch. MNS 578; lit. K rzy s z ow s k i 1981, s. 89 , ryc. $18: 1$.

18. Kołobrzeg (1), gm. Kołobrzeg, pow. Kołobrzeg, brzeg Bałtyku, znalezisko luźne, „radlica” - forma średniowysoka bez otworu - typ IB3,1121 - ryc. 2:1; wym. $22,0 \times 4,7 \times 4,5 \mathrm{~cm}$; zb.? (n. Muzeum Kołobrzeg); lit. S i u c h n iń s k i 1972, mapa II, poz. 31; Krzyszowsk i 1981, s. 105, poz. 108, tabl. 21:2.

19. Kołobrzeg (2), gm. Kołobrzeg, pow. Kołobrzeg, znalezisko luźne, ,radlica”, forma wysoka $z$ otworem prostopadlym do ostrza (tzw. Plättbolzen) - typ IB3,1133 ryc. 6:2; zb.? (n. Muzeum Kołobrzeg); arch. MNS 526; lit. Siuchniński 1972 , mapa II, poz. 31; Krzyszowski 1981, s. 106, poz. 110, ryc. 22:1.

20. Komnino (35), gm. Smołdzino, pow. Słupsk, znalezisko luźne, topór - typ IB3,1211; wym. ok. 13,5 ×4,0 ×3,2 cm; zb.? (n. szkoła w Gąbinie); lit. S i u c h n i ń ski 1972, mapa II, poz. 2.

21. Kończewo (28), gm. Kobylnica, pow. Słupsk, znalezisko luźne, siekiera o przekroju okragłym („Walzenbeile”) - typ IB3,1412 - ryc. 12; wym. 30,3 × 4,5 × 4,5 cm; zb. Muzeum Koszalin, nr kat. 1791; lit. Witt 1969, poz. 328. 
22. Kopań (27), gm. Darłowo, pow. Sławno, brzeg Bałtyku, znalezisko luźne (1999 r.), „radlica" - forma niska z otworem równoległym do ostrza - typ. IB3,1112 - ryc. 4:3; wym. 15,0 × 4,6 ×3,3 cm; zb. Muzeum Koszalin, nr kat. 15487; lit. I l k i e w i c z $2001 \mathrm{a}$, s. $155-161$.

23. Krępa Slupska (38), gm. Słupsk, pow. Słupsk, znalezisko luźne, „radlica” nieokreślona typologicznie z częściowo nawierconym otworem; zb.? (n. własność prywatna); lit. Witt 1969, poz. 311 .

24. Lojewo (39), gm. Damnica, pow. Słupsk, znalezisko luźne, siekiera o przekroju okraglym (,Walzenbeile”) - typ IB3,1411 - ryc. 11:1; wym. 16,3 ×5,7 ×4,6 cm; zb. Muzeum w Koszalinie, nr kat. 1820; lit. Wit t 1969, poz. 351.

25. Lojewo (40), gm. Damnica, pow. Słupsk, znalezisko luźne, fragment „radlicy” nieokreślonej typologicznie - ryc. 6:3; zb. Muzeum Koszalin, nr kat. 8767; arch. MK 956/Sł.; lit. W itt 1969, poz. 351.

26. Machowinko (31), gm. Ustka, pow. Słupsk, znalezisko luźne, „radlica” - forma niska lub średniowysoka $z$ otworem równoległym do ostrza - typ IB3,1112/1122; zb.? (n. własność prywatna); lit. W itt 1969, s. 26, poz. 255, ryc. 2/2; Siuchniński 1972, mapa II, poz. 3.

27. Machowino (32), gm. Ustka, pow. Słupsk, znalezisko luźne, ,radlica” - forma niska lub średniowysoka z otworem równoległym do ostrza - typ IB3,1112/1122; zb.? (n. Muzeum Słupsk); lit. W it t 1969, s. 26, poz. 161; Siuchniński 1972, mapa II, poz. 4.

28. Machowino (33), gm. Ustka, pow. Słupsk, znalezisko luźne, „radlica” - forma niska lub średniowysoka $z$ otworem równoległym do ostrza - typ IB3,1112/1122; zb.? (n. własność prywatna); lit. W itt 1969, s. 26, poz. 162.

29. Mielenko (12), gm. Mielno, pow. Koszalin, znalezisko luźne, „motyka” o asymetrycznym ostrzu - typ IB3,1332 - ryc. 10:3; wym. 10,0×4,0×21 cm; zb.? (n. własność prywatna); arch. MNS 633; lit. Krzyszowski 1981, s. 130-131, poz. 154, ryc. $27: 1$.

30. Niemica (15), gm. Malechowo, pow. Sławno, znalezisko luźne, topór - typ IB3, 1222 - ryc. 7:4; wym. 12,0 ×5,8 × 2,8 cm; zb. Muzeum Koszalin, nr kat. 9537; lit. Kleist 1969, s. 102, nr 480, ryc. 86; Siuchniński 1972, mapa II, poz. 20.

31. Osieki Słupskie (34), gm. Ustka, pow. Słupsk, znalezisko luźne, fragment „radlicy” niskiej lub średniowysokiej z otworem prostopadłym do ostrza (tzw. Plättbolzen) typ IB3,1113/1123 - ryc. 5:3; wym. zachowane $(6,7) \times 5,5 \times(1,9) \mathrm{cm}$; zb. Muzeum Koszalin, nr kat. 8849; arch. MK 520/Sł.; lit. W it t 1969, poz. 109?; S i u c h n ińs k i 1972, mapa II, poz. 1 (jako Gąbino).

32. Peplino (30), gm. Ustka, pow. Słupsk, znalezisko luźne, „radlica” nieokreślona typologicznie - typ I113/1123, 1133?; zb.? (n. Muzeum Słupsk, nr inw. 63); lit. W it t 1969, poz. 5; Siuchniński 1972, mapa II, poz. 5.

33. Runowo (42), gm. Potęgowo, pow. Słupsk, znalezisko luźne, ,radlica” (?) nieokreślona typologicznie; zb.? (n. Muzeum Słupsk, nr inw. 72); lit. W it t 1969, poz. 183; Siuchniński 1972, mapa II, poz. 6. 
34. Siecie (46), gm. Smołdzino, pow. Słupsk, znalezisko luźne, fragment topora - typ IB3, 1212 - ryc. 9:1; wym. zachowane $(6,5) \times 3,0 \times 2,5 \mathrm{~cm}$; zb. Muzeum Koszalin. nr kat. 1809; lit. Witt 1969, poz. 714.

35. Sierakowo (14), gm. Sianów, pow. Koszalin, znalezisko luźne, topór - typ IB3,121 - ryc. 9:2; wym. 16,3 ×6,0 × 5,0 cm; zb.? (n. Muzeum Darłowo, nr inw. 840); lit. Kle is t 1969 , s. 103 , nr $922 \mathrm{a}$, ryc. 91.

36. Slawno (25) - okolice (miejscowość nieznana) - dawny powiat Sławno, znalezisko luźne, ,radlica”, forma niska z otworem prostopadłym do ostrza (tzw. Plättbolzen) - typ IB3, 1113 - ryc. 5:4; wym. 12,0 × 8,4 ×3,0 cm; zb. Muzeum Koszalin, nr kat. 10199; arch. MK 372/S.

37. Sławno (26), gm. Sławno, pow. Sławno, znalezisko luźne, topór - typ IB3,12 11 ryc. 9:4; wym. $7,8 \times 3,5 \times 4,2 \mathrm{~cm}$; zb. Muzeum Koszalin, nr kat. 10358; lit. Kleist 1955 , s. 34 , nr 723 ; Kle is t 1969, s. 102, nr 723, ryc. 89.

38. Smardzewo (24), gm. Sławno, pow. Sławno, znalezisko luźne, topór - typ IB3, 1222 - ryc. 9:3; wym. 11,6 ×5,4×5,6 cm; zb. Muzeum Koszalin, nr kat. 10301; lit. $\mathrm{K}$ le ist 1969 , s. 102 , nr 738 , ryc. 89.

39. Stowięcino (45), gm. Główczyce, pow. Słupsk, znalezisko luźne, ,radlica” - forma niska lub średniowysoka z otworem równoległym do ostrza - typ IB3,1 112/1122; zb.? (n. Muzeum Slupsk, nr inw. 638); lit. K unkel 1934, s. 174; W it t 1969, poz. 584; S i u chniński 1972, mapa II, poz. 8.

40. Sycewice (41), gm. Kobylnica, pow. Słupsk, znalezisko luźne (1964 r.), „radlica” forma pośrednia pomiędzy niską i średniowysoką z otworem równoległym do ostrza - typ 1B3,1112/1122 - ryc. 4:2; wym. 17,5 × 5,4 × 4,3 cm; zb. Muzeum Koszalin, nr kat. 8774; arch. MK 559/S1.

41. Świecichowo (36), gm. Damnica, pow. Słupsk, znalezisko luźne, fragment topora typ IB3, 12 1; zb.? (n. Muzeum Słupsk, nr inw. 66); lit. W i t t 1969, poz. 553; S i u c h n ińs k i 1972, mapa II, poz. 9.

42. Świecichowo (37), gm. Damnica, pow. Słupsk, znalezisko luźne, „radlica” - typ IB3,1131 - ryc. 3 ; wym. $26,0 \times 7,0 \times 8,0 \mathrm{~cm}$; zb. Muzeum Koszalin, nr kat. 8781 ; lit. Kunkel 1934, s. 174; W it t 1969, poz. 555; S i u c hn ińs k i 1972, mapa II, poz. 9.

43.Święcianowo (17), gm. Malechowo, pow. Sławno, znalezisko luźne, „radlica” forma niska bez otworu - typ IB3,1111 - ryc. 2:3; wym. 14,2 ×4,0 × 3,0 cm; zb. Muzeum Koszalin, nr kat. 10254; lit. K le is t 1955, s. 37, nr 883; K le is t 1969 , s. 103 , nr 883, tabl. 91.

44. Unieście (13), gm. Mielno, pow. Koszalin, znalezisko luźne, topór - typ IB3,121 - ryc. 10:1; wym. 16,4 ×5,8 × 4,1 cm; zb.? (n. Muzeum Białogard, nr inw. 409); arch. MNS 669; lit. Siuchniński 1972, mapa II, poz. 24; Krzyszowski 1981, s. 230, ryc. 41:1.

45. Wielanowo (9), gm. Grzmiąca, pow. Szczecinek, znalezisko luźne, topór - typ IB3,1211 - ryc. 10:2; wym. 13,2 ×6,1 × 5,4 cm; zb. Muzeum Koszalin, nr kat. 10517; lit. Kle ist 1969 , s. 102, nr 723, ryc. 89.

46. Wieliszewo (43), gm. Potęgowo, pow. Słupsk, znalezisko luźne, ,radlica” - forma niska lub średniowysoka z otworem równoległym do ostrza - typ IB3, 1112/1122; 
zb.? (n. własność prywatna); lit. W it t 1969, poz. 639; S i u chn i ńs k i 1972, mapa II, poz. 10 .

\section{BIBLIOGRAFIA}

Brandt K.H.

1967 Studien über steierne Axte und Beile der jüngeren Steinzeit und der Steinkupferzeit Nordwestdeutschlands, Hildesheim.

Czerniak L.

1980 Rozwój spoleczeństw kultury późnej ceramiki wstęgowej na Kujawach [Sum.: The development of the Late Band Pottery Culture in Kujawy], Poznań.

1994 Wczesny i środkowy okres neolitu na Kujawach [Sum.: Early and middle period of the neolithic in Kuiavia], Poznań 1994.

Czerniak L., Kabaciński J.

1997 The Ertebølle Culture in Southern Baltic Coast, (w:) The Built Environment of Coast Areas During the Stone Age, red. D. Król, Gdańsk, s. 70-79.

Galiński T.

1990 Zespoty typu Tanowo. Zachodniopomorski Ekwiwalent ugrupowania Ertebølle-Ellerbek-Lietzow [Zus.: Die Fundplätze vom Typ Tanowo. Das westpommersche Equvalent der Komplekse Ertebølle-Ellerbek-Lietzow], „Materiały Zachodniopomorskie” t. XXXIII (1987), s. 53-122.

1992 Obozowiska mezolityczne i protoneolityczne na stanowisku w Tanowie badane w latach 1989 -1991 [Zus.: Mesolithische und protoneolithishe Lagerplätze auf der Fundstelle in Tanowo untersucht in den Jahren 1989-1991], „,Materiały Zachodniopomorskie” t. XXXVIII, s. 53-122.

1992a Uwagi na temat mezolitu ceramicznego i neolitu strefy leśnej na niżu polskim [Zus.: Bemerkungen zur Frage des keramischen Mesolithikums und des Neolithikums der Waldzone in der Polnischen Niederung], „Archeologia Polski” t. XXXVI (1991), z. 1-2, s. 5-71.

Grygiel R.

1976 Osady kultury ceramiki wstęowej rytej w Brzesciu Kujawskim kolo Wloclawka [Sum.: Settlements of the Linear Pottery (Danubian) Culture at Brześć Kujawski near Włoclawek], „Prace i Materiały Muzeum Archeologicznego i Etnograficznego w Łodzi, seria archeologiczna" t. 23, s. 5-114 (aneks: Narzędzia kamienne kultur ceramiki wstęgowej z Brześcia Kujawskiego [Sum.: Appendix, Stone implements of the Danubian Cultures at Brześć Kujawski], s. 102-111).

Ilkiewicz J.

1989 From Studies on Cultures of the $4^{\text {th }}$ Millenium BC in the Central Part of the Polish Coastal Area, „Przeglad Archeologiczny” t. 36, s. 17-55.

1997 From Studies on Ertebølle Type Cultures in the Koszalinian Coastal Area (Dabki 9, Koszalin-Dzierżęcino 7), (w:) The Built Environment of Coast Areas During the Stone Age, red. D. Król, Gdańsk, s. 50-65

1998 Osiedla proto-i wczesnoneolityczne na stanowisku $7 w$ Koszalinie-Dzierżęcinie [Zus.: Die protound frühneolithische Siedlungen auf der Fundstelle 7 in Koszalin-Dzierżęcino], „Acta Archaeologica Pomoranica" I, Szczecin, s. 41-51.

2001 Nieznane groby megalityczne w Dolinie Radwi (Mostowo, gm. Manowo, stanowiska 1 i 2), „Koszalińskie Zeszyty Muzealne" t. 23, s. 147-153.

2001 a Topór kamienny z mierzei jeziora Kopań (Kopań, gm. Darlowo, stanowisko 31), „Koszalińskie Zeszyty Muzealne" t. 23, s. 155-161.

Jankowska D.

1989 Spoleczności strefy potudniowo-zachodniobaltyckiej w dobie neolityzacji [Zus.: Gemeinschaften des südwestlichen Ostseeraums in der Neolithisierungszeit]. Poznań. 
Janocha H., Lachowicz F.J.

1972 Z pradziejów ziemi bialogardzkiej, (w:) Dzieje ziemi bialogardzkiej, red. A. Czarnik, Poznań, s. $25-70$.

Kleist D.

1955 Die urgeschichtlichen Funde des Kreises Schlawe, „3. Beiheft zum Atlas der Urgeschichte”, Hamburg.

1969 Die steinzeitlichen Funde des Kreises Schlawe, Pommersche Funde und Ausgrabungen aus den 30-er und 40-er Jahren, „11. Beiheft zum Atlas der Urgeschichte”. Hamburg.

Kobusiewicz M.

1999 Ludy lowiecko-zbierackie pólnocno-zachodniej Polski [Sum.: Hunting-Gathering Societies of North-Western Poland], Poznań.

Kondracki J.

1980 Geografia fizyczna Polski, Warszawa.

Krzyszowski A.

1981 Kultury neolityczne $w$ dorzeczu dolnej $i$ środkowej Parsęty (maszynopis pracy magisterskiej w archiwum działu archeologicznego Muzeum w Koszalinie).

Kunkel O.

1932 Einige Neufunde aus Pommern (Eine ostpreussische Felssteibeile aus Hinterpommern), „Mannus" Bd. 24, s. 270-279.

1934 Die Bandkeramik in Pommern, „Germania” Jh. 18, s. 173-178.

1938 Urgeschichte. Zugleich Bericht des Vertrauensmannes für die Kulturgeschichtlichen Bodenaltertümer in Pomern, „Baltische Funde” N.F., Bd. 40, s. 310-336.

Siuchniński K.

1969 Klasyfikacja czasowo-przestrzenna kultur neolitycznych na Pomorzu Zachodnim, cz. I: Katalog źródet archeologicznych [Vorbemerkungen], Szczecin.

1972 Klasyfikacja czasowo-przestrzenna kultur neolitycznych na Pomorzu Zachodnim. cz. II: Opracowanie analityczne [Zusammenfassung], Szczecin.

Vencl S.

1960 Kamenné nástroje prvnich zemédélců ve strédni Europé, „Sbornik Narodniho Muzea v Praze” vol. 14, nr 1-2, s. 1-91.

Wierzbicki J.

1999 Lupawski mikroregion osadniczy ludności kultury pucharów lejkowatych [Zus.: Lupawa-Siedlungsmikroregions der Bevölkerung der Trichterbecherkultur], Poznań.

Witt W.

1969 Übersicht über die urgeschichtlichen Epochen des Kreises Stolp, (w:) Pommersche Funde und Ausgrabungen aus den 30-er und 40-er Jahren, Hamburg. Hrsg. H.J. Eggers, s. 105-119.

Wiślański T.

1969 Podstawy gospodarcze plemion neolitycznych $w$ Polsce pólnocno-zachodniej [Sum.: Economic Basis of Neolithic Tribes in North-Western Poland], Wroclaw-Warszawa-Kraków.

1970 Uwagi o kulturze ceramiki wstegowej rytej w Polsce północno-zachodniej [Sum.: Some remarks on the Linear Band Pottery Culture in northwestern Poland], (w:) Z badań nad kulturq ceramiki wstegowej rytej, Kraków, s. 2936.

Zápotocká M.

1970 Die Stichbandkeramik in Böhmen und Mitteleuropa, (w:) Die Anfange des Neolithikums vom Orient bis Nordeuropa. Fundamenta, R.A, Bd. 3, Köln-Wien. 


\section{FRÜHNEOLITHISCHE STEINGERÄTE VOM KÜSTENSTREIFEN BEI KOSZALIN}

\section{Zusammenfassung}

Im Artikel wird der Versuch einer Klassifizierung und einer Analyse von 47 Steingeräten unternommen, welche im „Pobrzeże Koszalińskie” genannten Ostseeküstenstreifen gefunden wurden (Abb. 1). Es handelt sich nach der typologisch-chronologischen Taxonomie einerseits um Geräte, die mit dem Kulturkreis der Bandkeramik (23 Dechsel, 16 Äxte. 2 Hacken), sowie andererseits um solche, die zu den „,fühen nördlichen” Formen gerechnet werden (6 Beile mit rundem oder ovalem Querschnitt, sog. „Walzenbeile”). Mehrheitlich sind die Stücke leider Einzelfunde. Lediglich zwei Exemplare besitzen einen bestimmbaren kulturellen Kontext (eine „bandkeramische” Axt und ein „,nördliches” Beil vom Erteb, lle-Fundplatz Dŕbki 9 - Nr. 21 auf der Karte, Abb. 8,1; 13,3). Die Datierung dieser letztgenannten Geräte scheint darauf hinzuweisen, daß der Zufluß klassischer „,bandkeramischer” Geräte nach Pommern mit dem Rhythmus der Kulturveränderungen jener Phase in den besiedelten Gebieten übereinstimmt. Die Kartierung der Fundplätze zeigt ein völliges Ausbleiben frühneolithischer Steingeräte östlich des Flußtales der Łeba, woraus offenbar auf einen hauptsächlichen Zufluß aus dem Westen, entlang der Küste, zu schließen ist.

Den ältesten chronologischen Horizont repräsentieren die klassischen frühbandkeramischen flachen und mittelhohe „Dechsel” ohne Durchlochungen, die allgemein mit der Linienbandkeramik verbunden werden. Drei Exemplare wurden im westlichen Teil der Region entdeckt; sie überschreiten von Westen nicht den Fluß Grabowa. Möglicherweise kann man mit demselben Horizont die ältesten „nördlichen” Beile (Walzenbeile) verbinden, auch von ihnen liegen nur drei Stücke vor, die jedoch von Westen aus bis zur Słupia reichen. Den zweiten Horizont markieren als klassisch „spätbandkeramisch” bezeichnete Formen (hohe „Dechsel” ohne Durchlochung, niedrige und mittelhohe „,Dechsel” mit parallel zur Schneide verlaufender Durchlochung, Äxte, besonders solche mit unregelmäßigem Rücken) sowie generell frühe „,nördliche” Beile, darunter typologisch ,jüngere" Formen mit ovalem Querschnitt. Dieser Horizont ist mit der entschiedenen Mehrheit der Geräte verbunden und sicher mit den jüngeren Phasen der Linien- und der späten Stichbandkeramik zu parallelisieren.

Den dritten Horizont kennzeichnen „Plättbolzen” und sicher auch weiterhin die nicht unbedingt ausschließlich „,frühen” ,nördlichen” Äxte. Dieser überschreitet schon die Grenze des Frühneolithikums und man kann ihn allgemein als "frühbecherzeitlich" bezeichnen.

Eine gekürzte Gerätebeschreibung ist am Ende des Artikels in Form eines Kataloges beigefügt (Die Nummer in Klammern hinter der Ortsbezeichnung entspricht der Nummer auf der Karte Abb. 1). 